\title{
ESTUDIO SOBRE LA PRESCRIPCIÓN Y CADUCIDAD EN EL DERECHO DEL CONSUMO
}

\section{STUDY ON PRESCRIPTION AND LAPSE IN THE RIGHT CONSUMPTION}

\section{ESTUDO SOBRE A PRESCRIÇÃO E CADUCIDADE NO DIREITO DO CONSUMO}

Rodrigo Barcia Lehmann

\section{RESUMEN}

El presente trabajo tiene como objetivo analizar la prescripción extintiva y la caducidad en la LPDC. Para ello se hace un análisis doctrinal comparativo entre ambas figuras y se abordan los principales problemas que plantea la extinción de la acción civil -que proviene de la responsabilidad contractual o extracontractual- y su relación con la acción infraccional. Este análisis realiza un estudio de la relación entre ambas acciones -las civiles y las infraccionales- $\mathrm{y}$ los estatutos jurídicos que las rigen.

Palabras clave: prescripción, caducidad, ley del consumidor, violando la ley.

\section{AbStRACT}

This paper aims to analyze the statute of limitations and expiration in the LPDC. This is an analysis comparing both figures doctrinal and addres-

* Licenciado en Ciencias Jurídicas y Sociales, Universidad Central de Chile, 1991; MBA Economía y Dirección Internacional de Empresas, MEDI, Universidad Autónoma de Madrid, 1997; European Master in LAW and Economics, Complutense und Hamburg Universität, 1998; Doctor en Derecho Privado, Universidad Complutense de Madrid, 2002; profesor-investigador de la Facultad de Derecho de la Universidad Finis Terrae. Dirección postal: Universidad Finis Terrae, Facultad de Derecho, avenida Pedro de Valdivia $\mathrm{N}^{\mathrm{o}}$ 1509, Providencia, Chile. Artículo recibido el 30 de agosto de 2012 y aceptado para su publicación el 30 de octubre de 2012. Correo electrónico: rbarcia@uft.cl.

$\mathrm{El}$ autor agradece a la profesora Erika Isler por su ayuda con la búsqueda de alguna jurisprudencia y sus aportes al presente trabajo. 
ses major problems of extinction of the civil action, which comes from contract or tort, and its relation to the action infraction. This analysis makes a study of the relationship between the two actions, the civil and infraccionales-and legal statutes that govern it.

Keywords: prescription, forfeiture, consumer law, breaking the law.

\section{Resumo}

O presente trabalho tem como objetivo analisar a prescrição extintiva e a caducidade na $L P D C$. Para isso se faz uma análise doutrinal comparativa entre ambas figuras e aborda-se os principais problemas que coloca a extinção da ação civil -que provém da responsabilidade contratual ou extracontratual- e sua relação com a ação infracional. Nessa análise realizase um estudo da relação entre ambas ações -as civis e as infracionais-e os estatutos jurídicos que as regem.

Palavras chave: prescrição, caducidade, direito do consumo, infração à lei.

\section{INTRODUCCIÓN}

El estudio que se realiza a continuación se circunscribe al artículo 26 de la LPDC, que se refiere a la prescripción de la acción que persigue la responsabilidad contravencional y a la caducidad de las sanciones impuestas por la contravención. Los principales problemas que presenta el artículo precedente provienen de su ámbito de aplicación, que, para una parte importante de la doctrina, se restringe al ámbito infraccional, es decir, a la responsabilidad infraccional o contravencional, que se traduce fundamentalmente en las multas que impone el tribunal ${ }^{1}$. De este modo, se ha

${ }^{1}$ La responsabilidad infraccional a pesar de traer aparejadas por general multas, puede generar otros efectos. Así, Francisco Fernández señala que serían faltas infraccionales las siguientes: fallas o deficiencias atribuibles a negligencia del proveedor; cobro de un precio superior al exhibido, informado o publicitado; venta de sobrecupo o sobreventa; difusión de publicidad falsa o engañosa; suspensión, paralización o no prestación injustificada de servicios; omisión, falseamiento, ocultamiento o alteración de la rotulación; infracciones en el cobro de intereses por los créditos de consumo y las infracciones cometidas en la cobranza extrajudicial de créditos de consumo. Por otra parte, agrega el referido autor, el párrafo $5^{\circ}$, del título II, denominado disposiciones generales, de la ley incluye diversas normas orientadas a sancionar algunas conductas que entrañan incumplimiento de las obligaciones de los proveedores respecto del consumidor. Entre tales conductas las hay de signo doloso o culposo (que son las que se castigan como genuinas contravenciones, con pena de multa), en tanto que otras no 
entendido que la regulación del Consumo no se refiere a la prescripción de la acción civil, que eventualmente emana de la infracción estatutaria. Ello no deja de ser una paradoja, por cuanto la regulación actual habría omitido referirse a una materia tan relevante como la prescripción y caducidad de acción civil, que se le concede al consumidor por aplicación de la LPDC. Ello, como se verá no deja de ser extraño, desde que el Derecho contractual moderno, que regula el Derecho del Consumo, se ocupa de la prescripción y de la caducidad de una forma totalmente desconocida por nuestra legislación.

\section{ii. la caducidad y la prescripción extintiva}

El tiempo afecta las regulaciones contractuales y del consumo no sólo a través de la prescripción extintiva sino, también, a través de la caducidad o decadencia del plazo ${ }^{2}$. Esta última, en el Derecho Comparado, es una

comportan negligencia ni mala fe por parte del proveedor, pero como quiera que dan lugar a una ruptura de la conmutatividad del contrato de consumo en perjuicio del consumidor, la ley les asigna a una sanción de índole civil que en cada caso determina y que, en general, consiste en el deber de resarcir al consumidor afectado. Fernández Fredes, Francisco, Manual de Derecho chileno de protección al consumidor, Santiago, Editorial Lexis Nexis, 2003, p. 23.

${ }^{2}$ En este trabajo se analiza la caducidad sólo en cuanto al Derecho del Consumo, es decir, nos remitimos a aquélla establecida en la ley, como se desprende del artículo $26.3^{\circ}$ de la LPDC. No se consideran, por tanto, las formas de caducidad convencional (figura que se asemeja, en cierta medida, a la prescripción extintiva). La institución en estudio se desarrolla fundamentalmente en los artículos 2964 y 2965 del Codice Civil de 1942, como una institución que se diferencia de la prescripción extintiva. La prescripción presupone el abandono de un derecho, pero por la caducidad o decadencia se extingue un derecho por el mero transcurso del tiempo. Por ello, puede hacerla valer cualquiera, puede ser declarada de oficio y no se suspende ni se interrumpe, como sucede respecto de la prescripción extintiva.

En Chile tal vez, los autores que mejor han tratado este tema son Pedro Lira y Osvaldo Lagos. Pedro Lira, en su estudio de las fuentes alemanas, nos señalaba que los plazos extintivos no necesariamente dan lugar a la prescripción, sino -que para los efectos que nos interesan- pueden ser considerados como de caducidad. En esta materia desarrolla la clasificación de plazos extintivos, que planteara Alexander Grawein en 1880, los que dan lugar a varias figuras jurídicas. También Ramón Domínguez A. se ha ocupado de este tema, sin embargo, diferimos de este autor por cuanto sustenta que la diferencia fundamental entre ambas figuras es su ámbito de aplicación, circunscribiéndose la prescripción extintiva a los derechos patrimoniales y la caducidad a los derechos extrapatrimoniales.

Antonio Román García, "Prescripción y caducidad", en Código Europeo de Contratos, Pavia, Italia, Academia de Iusprivatistas Europeos, 2003, tomo II, p. 550; Pedro LiRA URQUIETA, "Concepto jurídico de caducidad y prescripción extintiva", en Revista de Derecho y Jurisprudencia, edición bicentenario, doctrinas esenciales, derecho civil, obligaciones, tomo II, Santiago, 2009, pp. 598, también en RDJ, tomo 24, Derecho, Santiago, 1927, pp. 144168; Osvaldo Lagos Villarroel, "Para una recepción crítica de la caducidad", en Revista Chilena de Derecho Privado, No 4, Santiago, julio 2005, pp. 81-105 y Ramón Domínguez 
limitación temporal de la acción por efecto de la falta de daño, de identidad del victimario o cualquier otra circunstancia que impida que se pueda entablar la acción. En este sentido, Fernando Reglero -refiriéndose al Derecho de Consumo español- nos señala como ejemplo de decadencia la acción establecida en el artículo 13 de la LRCPD. En virtud de esta disposición los derechos del perjudicado se extinguen por el transcurso de diez años, desde la fecha en que se hubiera puesto en circulación el producto concreto causante del daño, salvo que se hubiese, durante dicho período iniciado la correspondiente reclamación judicial ${ }^{3}$. Es relevante señalar que existen

Águila, La prescripción extintiva. Doctrina y jurisprudencia, Santiago, Editorial Jurídica de Chile, 2004, No 28, p. 140.

${ }^{3}$ Esta tendencia se puede apreciar en los artículos 10 y 11 de la directiva 85/374/ CEE, relativa a la responsabilidad por productos defectuosos. En virtud de la segunda de estas normas, la responsabilidad del productor se extingue a los diez años de la fecha en que puso el producto en circulación, a menos que existan reclamaciones o procesos pendientes, es decir, se establece una forma de caducidad del derecho. Por otra parte, como plazo de prescripción, de la acción de reclamación por un producto defectuoso, se establece un plazo de tres años a contar de la fecha en la que tuvo o hubiera debido tener conocimiento de la existencia del daño, del defecto y de la identidad del productor. De este modo, las disposiciones con comento son del siguiente tenor:

"Artículo 10.

$1^{\circ}$ Los Estados miembros dispondrán en sus legislaciones que la acción de resarcimiento prevista en la presente Directiva para reparar los daños, prescribirá en el plazo de tres años a partir de la fecha en que el demandante tuvo, o debería haber tenido , conocimiento del daño, del defecto y de la identidad del productor.

$2^{\mathrm{O}}$ Las disposiciones de los Estados miembros que regulen la suspensión o la interrupción de la prescripción no se verán afectadas por la presente Directiva.

Artículo 11.

Los Estados miembros dispondrán en sus legislaciones que los derechos conferidos al perjudicado en aplicación de la presente Directiva se extinguirán transcurrido el plazo de diez años a partir de la fecha en que el productor hubiera puesto en circulación el producto mismo que causó el daño, a no ser que el perjudicado hubiera ejercitado una acción judicial contra el productor".

A pesar de que en la directiva se estableció este plazo de prescripción de tres años y de caducidad de diez años, se discutió sobre la ampliación de este último. Los argumentos a favor de su ampliación se basaron en un juicio acaecido en Francia. En dicho país, varias mujeres embarazadas tomaron un medicamento que causó daños físicos a sus hijos, los que recién se manifestaron en la edad de madurez sexual, véase la n. 19 del segundo informe sobre la aplicación de la directiva 85/374/CEE; pero se optó por desechar estas críticas y mantener los plazos por razones de seguridad jurídica.

Zinaída GonZÁLEz BlanCo-RaChewsKY, "Japón: nueva ley de responsabilidad civil por los daños causados por productos defectuosos", en Estudios sobre consumo, No 31, España, octubre 1994, pp. 37-46.

Esta tendencia sería seguida en varios países. De esta forma, el artículo 5 de la ley japonesa $\mathrm{N}^{\mathrm{o}}$ 85/1994, de 1 de julio, sobre responsabilidad civil por los daños causados por productos defectuosos, establece la misma precisión precedente. 
diferencias entre estas figuras por cuanto la prescripción extintiva, como acertadamente han entendido nuestros tribunales -a lo menos en materia de responsabilidad extracontractual-, exige que el daño haya acaecido, sólo desde ese momento comenzará a correr el plazo de prescripción. Por esto, para ella que opere, la acción no sólo debe ser exigible sino, también, debe ser ejecutable. Así, los derechos no ejecutables no prescriben, sino caducan. Antonio Román define la caducidad o decadencia ${ }^{4}$, como el término fijo para la duración de un derecho, surgido por la voluntad de las partes o disposición de la ley ${ }^{5}$. Ésta es inherente al derecho subjetivo en cuanto facultad

${ }^{4}$ En los artículos 129, por una parte, y 134 a 136, por la otra, del Pavia, se regulan la caducidad y la prescripción extintiva. La caducidad entraña una pérdida respecto de la emisión de una declaración o para el cumplimiento de un acto y la prescripción extintiva es la pérdida del ejercicio de todo derecho que pueda derivar del contrato. Como destaca Joaquín Arce Flórez-Valdés, los elementos comunes entre estas figuras son: el silencio de la relación jurídica, el transcurso del tiempo, sin ejercer un derecho o facultad, y su común sustrato ideológico: la seguridad jurídica. A pesar de que la doctrina crítica la falta de precisión de estos conceptos en el Pavia, ello obedece a sus límites, que son el respecto de culturas jurídicas diferentes. Por ello, la prescripción supone un elemento valorativo respecto del acreedor, que es la pérdida del derecho que exige su inacción; en cambio, la caducidad es externa al acreedor, viene dada por la decadencia del contrato. Para Joaquín Arce la decadencia o caducidad es una ineficacia, muy similar a la nulidad.

Lo que se pone de manifiesto en la regulación de Pavia, para Antonio Román, es que la prescripción no determina la extinción de un derecho en sentido estricto, sino la imposibilidad definitiva del ejercicio del mismo.

La misma tendencia se puede apreciar en los artículos 14:501 de los PECL y III-7:101 del DCFR. De este modo, en la sección $5^{\text {a }}$ de los PECL (artículos 14:501 a 14:503) se regulan los efectos de la prescripción en los siguientes términos:

"Article 14:501: GENERAL EFFECT

(1) After expiry of the period of prescription the debtor is entitled to refuse performance.

(2) Whatever has been performed in order to discharge a claim may not be reclaimed merely because the period of prescription had expired.

Article 14:502: EFFECT ON ANCILLARY CLAIMS

The period of prescription for a right to payment of interest, and other claims of an ancillary nature, expires not later than the period for the principal claim.

Article 14:503: EFFECT ON SET-OFF

A claim in relation to which the period of prescription has expired may nonetheless be set off, unless the debtor has invoked prescription previously or does so within two months of notification of set-off".

El capítulo XIV de los Principios Lando regula de forma general la prescripción extintiva. Pero, además, ella no opera de pleno derecho, conforme a los artículos $10.9^{\circ} \mathrm{de}$ los PICC y 24 de la Convención de Naciones Unidas sobre Compraventa Internacional de Mercaderías.

Román (n 2), pp. 539-540 y Joaquín ArCe Flórez-VAldés, "Extinción del contrato y de las relaciones que nacen del mismo", en Código Europeo de Contratos, Pavia, Italia, Academia de Iusprivatistas Europeos, 2003, tomo II, pp. 537-538.

${ }^{5}$ Román (n. 2), p. 548. 
$y$, consecuentemente, opera de pleno derecho ${ }^{6}$. En cambio, la prescripción extintiva es una limitación temporal que requiere de la concurrencia de un elemento volitivo del deudor, como es el que deba alegarse. La prescripción afecta de forma excepcional a la obligación, por cuanto de no ser alegada la acción no prescribe. El juez, en la caducidad, se limita a reconocer que un derecho ya se encuentra extinto ${ }^{7}$. En este sentido, ambas figuras tienen el mismo sustento -que es la seguridad jurídica- por cuanto la caducidad o decadencia evita que el sujeto pasivo quede obligado civilmente a reparar el ilícito por un tiempo más allá de lo razonable ${ }^{8}$. Esta diferencia se plasma, en que, como destaca Antonio Román, siguiendo a José Puig Brutau:

"la caducidad se refiere fundamentalmente a derechos potestativos, desde la perspectiva de atribuir a un sujeto la potestad de producir, por su declaración de voluntad, la creación, modificación o extinción de una relación jurídica"9.

En este sentido el deudor está sujeto a un derecho potestativo, que se extingue naturalmente por el transcurso del tiempo ${ }^{10}$. Los referidos au-

${ }^{6}$ Este punto, sin embargo, es controversial desde que autores como Andrés Domínguez Luelmo y Henar Álvarez Álvaez señalan que los efectos de la prescripción, con relación al transcurso del tiempo, en el Derecho Comparado, admite dos sistemas:

a) La extinción automática de los derechos y acciones, es decir, en estos ordenamientos jurídicos la prescripción extintiva opera como la caducidad. De este modo, el juez puede declararla de pleno derecho y la consecuencia más relevante de ello es que si el deudor paga puede accionar por el pago de lo no debido.

b) El transcurso del tiempo puede ser invocado por el deudor frente a la demanda del acreedor. Andrés Domínguez Luelmo y Henar Álvarez Álvarez, "La prescripción en los PECL y en el DCFR", en INDRET, No 3, 2009, disponible en www.indret.com/ pdf/654_es.pdf. Consultada el 6 de julio de 2012.

${ }^{7}$ Esta diferencia no está demasiado clara en nuestro Derecho, desde que algunas sentencias han entendido que la prescripción, independientemente que deba ser alegada, opera de pleno derecho. A esta posición se refiere Francisco Escalona Riveros cuando señala: "nuestros tribunales han tenido la oportunidad de pronunciarse al respecto, y han señalado que la prescripción existe desde antes de su declaración judicial”. El referido autor cita unas sentencias que avalan dicha posición y otras que la atacan. Francisco Escalona Riveros, La prescripción extintiva civil, Santiago, Conosur, 1997, p. 27.

${ }^{8}$ Fernando Reglero Campos, "La prescripción de la acción de reclamación de daños", en Fernando Reglero CAmpos (coord.), Lecciones de responsabilidad civil, Navarra, España, Aranzadi, 2002, pp. 161-162.

${ }^{9}$ Sin perjuicio de lo señalado, la referencia a los derechos potestativos, como categoría diferenciadora entre prescripción y caducidad, ha sido fuertemente criticada por la doctrina comparada. Ello se debe a que no ha sido posible determinar de forma precisa lo que se entiende por dicho concepto. LaGos (n. 2), p. 87.

${ }^{10}$ Por ello, de no ejercerse la potestad, se entiende que el derecho no ha existido nunca y además ello explica que los plazos de caducidad sean extensos. Román (n. 2), p. 551. 
tores agregan que la caducidad afecta al derecho mismo, en cambio, la prescripción sólo afecta su exigibilidad ${ }^{11}$. Por otra parte, lo esencial de la caducidad es que el derecho no llega a nacer, por cuanto no se dan las condiciones para su constitución, o concurriendo dichas condiciones, el derecho no se ejerce. En este último supuesto, el derecho sólo puede ejercerse dentro del plazo.

Osvaldo Lagos destaca las diferencias más relevantes entre ambas figuras. Así, la caducidad opera ipso iure, por lo que no requiere ser invocada; no admite suspensión ni interrupción; las partes no pueden extender su vencimiento y puede ser pactada convencionalmente.

Por último, la diferencia fundamental entre prescripción extintiva y caducidad viene dada por el interés protegido. En la prescripción extintiva lo que se protege es el interés particular del deudor, en cambio, en la caducidad lo esencia es la protección del interés publico ${ }^{12}$.

\section{iii. la regulación de la prescripción extintiva y la caducidad en el artículo 26 de la LPDC}

La extinción de una obligación puede producirse de forma directa por un modo de extinguir las obligaciones, como es el caso de la prescripción extintiva, y de forma indirecta mediante la extinción del contrato. Sin perjuicio de lo cual, en nuestro Derecho, existe un cierto consenso en que la prescripción extintiva afecta a la acción civil, y no a la obligación por cuanto, de acuerdo con el artículo $1470.4^{\circ}, \mathrm{N}^{\mathrm{o}} 2$ del $C C C h$, las obligaciones civiles prescritas subsisten como naturales. Por ello, la prescripción extintiva sólo afecta la exigibilidad de la obligación, pero otorga derecho a retener lo dado o pagado en razón de ella. Este punto se ha discutido también en el Derecho Comparado y en los PECL, de acuerdo con el artículo 14:101, lo que prescribe es la acción (claim) y en la DCFR, conforme al artículo III-7:101, lo que prescribe es el derecho (rights). En cambio, como se sostiene hace tiempo en el Derecho alemán, lo que prescribe es la pretensión (Ansprüche). Esta última posición tiene mucho sentido, desde que modernamente se ha insistido, desde el Derecho de la Contratación europea, como desde los países del Common Law, que los efectos de las obligaciones se centran en las expectativas rotas del acreedor. Estas expectativas rotas se satisfacen para el referido Derecho Moderno europeo a través del denominado Derecho de Remedios y para los países del Common Law a través de la indemnización de perjuicios. Así, en los artículos $123.3^{\circ}$ y 143 del texto refundido de la Ley General para la

${ }^{11}$ Román (n. 2), p. 549.

${ }^{12}$ Así se ha entendido por la doctrina. Ello a pesar de que la prescripción también puede justificarse en consideraciones económico-sociales. 
Defensa de los Consumidores y Usuarios y otras Leyes Complementarias del 2007 (española) lo que prescribe es: "la acción para reclamar el cumplimiento de la responsabilidad del vendedor y derechos del consumidor y usuario" y la "acción de reparación de los daños y perjuicios", en un plazo de tres años desde la entrega del producto o de su defecto, respectivamente. A su vez, la interrupción de la prescripción, de acuerdo con el artículo $143.2^{\circ} \mathrm{del}$ texto refundido de la Ley General para la Defensa de los Consumidores y Usuarios y otras Leyes Complementarias del 2007 (española), se rige por el Código Civil español.

Entre nosotros, el artículo 26 de la LPDC diferencia entre la prescripción contravencional, que puede generar responsabilidad civil, que está regulada en el inciso primero, y la obligación que trae aparejada la condena civil infraccional, de la que se ocupa el inciso $3^{013}$. Esta técnica legislativa por la cual se distingue entre una plazo de prescripción (en el inciso $1^{\circ}$ de la norma precedente) y de caducidad (en el inciso $3^{\circ}$ ), como hemos podido analizar, nos es familiar. Así, el acreedor, en este último supuesto, puede ejercer el derecho potestativo, que reconoce la sentencia judicial, dentro del período de un año a contar desde que la sentencia produce el efecto de cosa juzgada o queda a firme. Esta norma establece una forma de caducidad que afecta un derecho personal ya constituido y que puede ejercerse potestativamente por el titular del derecho. En cambio, el inciso primero establece un plazo de prescripción de la acción más breve.

Una vez realizado este análisis general nos detendremos en el ámbito de aplicación del artículo 26 de la LPDC, y luego abordaremos algunos aspectos generales en torno a la caducidad.

${ }^{13}$ En el proyecto que enviara el Ejecutivo, en su artículo 20, se señalaba: "las acciones que persigan la responsabilidad contravencional que se sanciona por la presente ley prescribirán en el plazo de seis meses.

Las sanciones impuestas por dichas contravenciones prescribirán en el término de un año contado desde que hubiere quedado a firme la sentencia condenatoria".

La redacción actual de la norma obedece a la indicación sustitutiva $\mathrm{N}^{\circ} 114$, que reemplazó en el inciso primero, la frase "desde la recepción del producto o terminación del servicio" por la siguiente: "desde que se haya incurrido en la infracción respectiva". Esta indicación ya había sido desechada por la Cámara de Diputados (Primer Informe de la Comisión de Economía), pero fue repuesta y aprobada en el Senado por la unanimidad de los miembros de la Comisión de Economía (senadores Olga Feliú, Sergio Bitar, Francisco Prat, Sergio Romero y Adolfo Zaldívar). La indicación del Ejecutivo, desechada en la Cámara de Diputados, incluía una referencia a desde cuando se cuenta el pazo en caso de publicidad engañosa, que señalaba que en caso "de difusión de publicidad o información falsa o engañosa en cuyo caso se debe contar el plazo de prescripción desde la fecha de la última emisión del respectivo anuncio o mensaje". Historia de la Ley, en www.leychile. cl/Consulta/portada_hl, pp. 379 y 575. Consultada el 6 de julio de 2012. 
1. Reglas en torno al ámbito de aplicación de la prescripción extintiva

El ámbito de aplicación del artículo 26 de la LPDC ha dado lugar a una nutrida jurisprudencia de los tribunales de justicia, y a una clara posición de la doctrina de consumo, que conduce a restringir su ámbito de aplicación. A continuación, se desarrolla el estado de la discusión doctrinal y las tendencias jurisprudenciales en torno a dicho ámbito de aplicación.

a. La posición predominante en la jurisprudencia de los tribunales: la prescripción de la acción infraccional genera la caducidad de la acción civil

La posición preponderante para la jurisprudencia ha sido que la prescripción de la responsabilidad infraccional produce la caducidad de la acción civil $^{14} \mathrm{e}$, incluso, algunos fallos han resuelto que ambas acciones prescriben conforme al artículo $26.1^{\circ}$ de la LPDC. Así, para Juan Ignacio Contardo,

"la gran parte de la jurisprudencia determina que cualquier ilícito civil implica una sanción infraccional, por lo menos basada en el artículo 24".

En este sentido, la aplicación general de la responsabilidad infraccional estaría dada por la norma precedente, que establece:

"las infracciones a lo dispuesto en esta ley serán sancionadas con multa de hasta 50 unidades tributarias mensuales, si no tuvieren señalada una sanción diferente".

Los argumentos fundamentales dados a favor de esta posición, serían los siguientes:

a) Los fallos señalan que la responsabilidad civil autónoma no existe, de manera que siempre se requiere de una sanción administrativa.

${ }^{14}$ Ello sucede aun si se estima que el artículo 26 de la $L P D C$ sólo regula la responsabilidad administrativa del productor, es decir, la aplicación de multas. Esta conclusión es consecuencia de entender que la acción civil depende de la acción infraccional. La doctrina, como veremos en el presente trabajo, critica esta posición por cuanto la acción civil sería una acción dependiente de la sanción infraccional y se violaría uno de los principios fundamentales del Derecho Privado, como lo es el principio de la reparación integral del daño. 
b) La acción infraccional acarrea la prescripción de la acción civil o se entiende que el plazo es el mismo para ambas acciones ${ }^{15}$.

c) Para Francisca Barrientos:

"el fundamento de esta tesis se encontraría en los artículos 23 y 24 que establecen la regla general de las infracciones de la LPDC; entonces, todas las disposiciones de la ley que no contengan sanciones deberían ser penadas con infracciones traducidas en multas de hasta 50 UTM. Como sería el caso del plazo de prescripción de la acción de nulidad, que no cuenta con una norma determinada en la LPDC. Asimismo, en virtud de los artículos 9 y 14 de la ley $\mathrm{N}^{\mathrm{o}} 18.223$, el juez de policía local naturalmente conoce denuncias infraccionales y aplica multas, con lo que no podría conocer causas que contengan sólo aspectos civiles"16.

A este respecto Ruperto Pinochet nos aclara:

"la gran mayoría de los Juzgados de Policía Local considera imprescindible sancionar infraccionalmente a una empresa, aplicando multas correspondientes a beneficio fiscal, como requisito de procedencia para después condenarla a indemnizar perjuicios en virtud de las disposiciones de la Ley de Protección al Consumidor. Así, de acuerdo a la lógica expuesta, si el demandado no es condenado infraccionalmente, el consumidor o usuario, que debiera encontrarse protegido por las disposiciones de la Ley 19.496, pierde su derecho a ser indemnizado por los perjuicios sufridos por el acto doloso o culpable que los ha causado".

${ }^{15}$ Juan Ignacio ConTARdo GonzÁlez, "Prescripción de la acción indemnizatoria en la Ley de Protección al Consumidor: tendencias jurisprudenciales", en Cuadernos de Extensión Jurídica, No 21, Santiago, Universidad de los Andes, 2011, pp. 93-94.

En realidad esta posición se basaba en la redacción que tenía el artículo $50.1^{\circ}$ de la $L P D C$, antes de la ley $\mathrm{N}^{\circ} 19955$. Sin embargo, esta interpretación era un tanto antojadiza por cuanto la referida norma establecía: "será competente para conocer de las acciones a que da lugar la aplicación de la presente ley el juez de policía local de la comuna en que se hubiere celebrado el contrato respectivo, o en su caso, se hubiere cometido la infracción o dado inicio a su ejecución”. La interpretación de la jurisprudencia mayoritaria parece antojadiza por cuanto la ley era clara al otorgar competencia al juez de policía local respecto "de las acciones a que da lugar la aplicación de la presente ley", es decir, respecto de todas ellas (civiles e infraccionales) y la competencia era determinada por la celebración del contrato, o de proceder sólo la acción infraccional, por el lugar donde se hubiere cometido o dado inicio su ejecución.

${ }^{16}$ Francisca Barrientos Camus, "Derecho del Consumo", en Revista Chilena de Derecho Privado, No 17, Santiago, diciembre 2011, p. 273. 
Incluso, se ha resuelto que el plazo de prescripción extintiva para esta acción es el mismo que para la acción infraccional. Así, para el fallo de la Corte de Apelaciones de Santiago, de 2 de junio de 2009, el artículo $26.1^{\circ}$ de la LPDC es de aplicación general y comprende las acciones civiles ${ }^{17}$.

\section{b. La posición de la mayoría de la doctrina de Derecho del Consumo y algunos fallos relevantes de los tribunales: la prescripción extintiva del artículo $26.1^{\circ}$ de la LPDC sólo se aplica a la acción infraccional}

La doctrina chilena ha reaccionado en contra de la doctrina de los tribunales señalada y ha intentado restringir al máximo la aplicación del artículo $26.1^{\circ}$ de la LPDC. De esta forma, "la responsabilidad contravencional" -a que hace referencia el inciso $1^{\circ}$ de la norma precedentese aplicaría exclusivamente al campo infraccional. La responsabilidad infraccional cumpliría sólo una función sancionadora o punitiva, en el Derecho de Consumo, y no una función resarcitoria, que es propia de la responsabilidad civil. Por ello, esta norma no regularía -a lo menos de forma directa- la prescripción de la acción civil, que tenga su origen en la

${ }^{17}$ El fallo de la Corte Suprema, de fecha 15 de julio del 2009, Ing. No 3774-09, desestimó un recurso de queja contra la sentencia de la CA de Santiago, de 2 de junio del 2009, Ing. $\mathrm{N}^{\mathrm{o}}$ 5380-09. A su vez, la CA había confirmado la sentencia del JPL de Renca, de fecha 9 de diciembre de 2008, rol No 8029-1-06, pronunciado en los autos SERNAC con Lan Chile S.A. Pero, la Corte Suprema sin analizar el fondo del asunto declaró inadmisible la queja que presentara la recurrente. En el considerando segundo, de la sentencia de la Corte Suprema, se resuelve: "el recurrente pretende discutir en sede disciplinaria un asunto ya resuelto a través de las instancias respectivas, lo que importa que ya se ha hecho uso de otros recursos legales". En cambio, la sentencia de la Corte de Apelaciones de Santiago había resuelto, en su considerando tercero: “...el mismo plazo de prescripción procede aplicar respecto de la acción civil que persigue la indemnización de los perjuicios derivados de la infracción, con la diferencia que el hecho que interrumpe el plazo de prescripción es la notificación de la demanda civil, por cuanto corresponde aplicar las normas generales sobre la materia, al no existir norma especial". Véase: www.poderjudicial.cl/modulos/ BusqCausas/BCA_estados_causas.php. Consultada el 6 de julio de 2012.

En contra de la sentencia precedente, el fallo de la Corte de Apelaciones de San Miguel, de fecha 17 de mayo de 2010, Ing. N ${ }^{\circ}$ 187-2010, recaído en los autos SERNAC con Braun Medical S.A., confirmó la sentencia del JPL San Bernardo, de fecha 18 de enero de 2010, rol 3422-4-2008, resolviendo, en su considerando trigésimo quinto, que “...por lo demás, el artículo 26 de la Ley No 19.496, sólo se refiere a las acciones que persiguen la responsabilidad contravencional que se sanciona por la Ley $\mathrm{N}^{\circ} 19.496$ y a las sanciones impuestas en definitiva, pero no alude para nada a las acciones civiles, de que se trata el presente caso y cuya prescripción se gobierna por el derecho común. Lo contrario significaría aceptar que la Ley de Protección al Consumidor, fijó un plazo de prescripción especial para las acciones indemnizatorias de los consumidores de seis meses". 
responsabilidad contractual o extracontractual ${ }^{18,19}$. Por tanto, la aplicación de esta disposición estaría circunscrita a la responsabilidad infraccional, y excluye la responsabilidad civil ${ }^{20}$. En este sentido, "a responsabilidad contravencional" no comprendería la responsabilidad estatutaria, que podría provenir del contrato o de la propia ley, aunque ella se sustente en el Derecho del Consumo ${ }^{21}$.

Juan I. Contardo y Ruperto Pinochet, señalan que una parte importante de la doctrina y algunos pocos fallos de los tribunales han resuelto que la acción civil es independiente de la función sancionatoria de los juzgados de policía local. Como consecuencia de ello, es posible entablar una acción civil, sin requerir la aplicación de la responsabilidad infrac-

${ }^{18}$ Uno de los primeros autores en abordar este tema fue Bruno Caprile. Para el referido autor nada impide, una vez que se agotan o prescriben las acciones a que da lugar la LPDC, recurrir al Derecho Común. Bruno Caprile analiza la prescripción, a la que se refiere el artículo 21 de la LPDC, y nos señala: "prescritas las acciones civiles que concede la LPC, el consumidor podrá ejercer las que le confiere el Derecho Común, Civil o Comercial' (lo destacado es del autor. Bruno Caprile Biermann, "Las acciones del comprador insatisfecho: el cúmulo actual (Ley de Protección al Consumidor, vicios redhibitorios, error sustancial, resolución por incumplimiento) y la tendencia al deber de conformidad en el Derecho comparado", en Fabricio Mantilla Espinosa y Carlos Pizarro Wilson (coordinadores), Estudios de 126 Derecho Privado en homenaje a Christián Larroumet, Santiago, Ediciones de la Fundación Fernando Fueyo Laneri, 2008, p. 571. Una versión más embrionaria de este texto está en Bruno Caprile Biermann, "Las acciones del comprador insatisfecho: el cúmulo actual y la tendencia al deber de conformidad", en Hernán Corral y María Rodríguez, Estudios de Derecho Civil II (IV Jornadas de Derecho Civil), Olmué, Santiago Lexis Nexis, 2006, pp. 648-650. n. 18

${ }^{19}$ De este forma Juan I. Contardo nos señala: "de la simple lectura del articulado de la $L P D C$ puede señalarse que ésta no consagra una regulación particular sobre la prescripción liberatoria de la acción civil indemnizatoria, tanto en supuestos de responsabilidad contractual como extracontractual". CONTARdo (n. 15), p. 90.

${ }^{20}$ Nuestra regulación en este sentido sería bastante sui generis por cuanto no se ocupa, como lo hace el Derecho Comparado de la extinción (prescripción y caducidad) de la acción (claim) en los PECL, de los derechos (rights) en la DCFR o de la pretensión en el Derecho alemán, sino solamente de una "prescripción infraccional".

${ }^{21} \mathrm{El}$ sustento de esta responsabilidad infraccional es un derecho disuasivo o sancionador, alejado del principio del resarcimiento integral del daño, propio del Derecho Civil. Ello es fácilmente justificable en las palabras de Ricardo Sandoval cuando señala: "en el caso de ciertas infracciones de especial gravedad las multas son de mayor envergadura. Así por ejemplo, si se trata de difusión de publicidad falsa o engañosa, efectuada a través de medios masivos de comunicación, cuando incida en las cualidades de productos o servicios que afecten la salud o seguridad de la población o el medio ambiente, conducta que es castigada con multa de alto monto. Lo mismo ocurre en el caso de negativa o de interrupción injustificada de servicios previamente contratados y por los cuales se haya pagado derecho de conexión, instalación, o mantención”. Ricardo SANDoval López, Derecho del Consumidor, Santiago, Editorial Jurídica de Chile, 2004, p. 177. Sin perjuicio de lo anterior, es discutible que el Derecho Privado no tenga un papel disuasivo o preventivo. 
cional $^{22}$. La posición doctrinal precedente afecta a la prescripción, por cuanto dicha posición determina el ámbito de aplicación del artículo 26 de la LPDC. Así, las reglas de la prescripción extintiva, de acuerdo a la doctrina precedente, estarían dadas, respecto de la responsabilidad civil no infraccional, por el Código Civil y no por el artículo 26 de la LPDC. El ámbito de aplicación de la norma en estudio, de acuerdo a esta última posición, es restringido y estaría dado por la función sancionadora del Derecho del Consumo, y no por la función resarcitoria propia de la responsabilidad civil.

Los argumentos a favor de esta posición, como destacan Bruno Caprile, Ruperto Pinochet, Juan Ignacio Contardo y José Luis Guerrero, serían los siguientes:

a) Los juzgados de policía local, desde una perspectiva histórica, están vinculados a un derecho de faltas en el ámbito comunal. Ello hizo

${ }^{22}$ En consecuencia, Ruperto Pinochet y Juan I. Contardo se inclinan por un ámbito de aplicación restrictivo del artículo 26 de la LPDC, y ordenan los fallos y doctrina que están a favor y en contra de esta posición. A favor de la posición mayoritaria, que Ruperto Pinochet critica, están las siguientes sentencias: Reyes Yáñez con Alimentos Fruna, JPL de Maipú; Bernal con VTR, Corte de Valparaíso 8 de noviembre de 2004, acción se desestima por no acreditarse la infracción; Muñoz con Mueblería Peña y Morales, JPL de Antofagasta; Ehrenfeld con Líder Antofagasta,JPL de Antofagasta; Muñoz con Comercial Las Brujas, Corte de Apelaciones de Concepción 5 de septiembre de 2008; Ávila Jiménez y SERNAC con A and V Mercado de Conveniencia, Corte de Santiago 19 de septiembre de 2008, rol 5587-2008. Francisca Barrientos agrega que la posición que hace sinónimos responsabilidad infraccional y civil es generalizada en el Derecho del Consumo y cita la siguiente jurisprudencia: Muñoz con Mueblería Peña y Morales, Juzgado de Policía Local de Antofagasta, 26 de agosto de 2008, rol No 5216-2008; Menares con Almacenes París, Juzgado de Policía Local de Antofagasta, 15 de julio de 2008, rol No 3704-2008; Mujica con Castro, Juzgado Policía Local de Antofagasta, 30 de junio de 2009, rol N ${ }^{\circ}$ 3788.2009. En la línea de la responsabilidad por publicidad engañosa Castillo y otros con Corporación Santo Tomás, Corte de Apelaciones de Temuco, 4 de diciembre de 2008, rol No 934-2008, Legal Publishing No 41433; Bevilacqua con Instituto Profesional Santo Tomás, Corte de Apelaciones de Antofagasta, 5 de febrero de 2009, rol No 143-2008, Legal Publishing $N^{\circ}$ 417682. Desde el punto de la vista de la garantía legal, véase Cepeda con Comercial Automotora Prime, Tercer Juzgado de Policía Local de Antofagasta, 26 de octubre de 2008, rol No 7325-2008; Langanbach con Supermercado Jumbo, Segundo Juzgado de Policía Local de Maipú, 17 de julio de 2007, rol No 5265-2006, entre otros. Indirectamente véase Varas con Empresa La Polar, Corte de Apelaciones de La Serena, 8 de agosto de 2007, rol No 144-2007, Legal Publishing No 36982.

Finalmente, a favor de la posición de los autores precedentes se inclinan Emilio Pfeffer Urquiaga, Gonzalo Cortéz Matcovich y José Luis Guerrero Becar.

Ruperto Pinochet Olave, “¿Es necesaria la condena infraccional como requisito de procedencia a la indemnización de perjuicios regulada en la Ley 19.496 sobre protección del consumidor? Un error histórico", en Fabián Elorriaga de Bonis (coord.), Estudios de Derecho Civil VII. Jornadas Nacionales de Derecho Civil, Viña del Mar, Santiago, Thomson ReutersAbeledoPerrot, 2011, pp. 428-429; Contardo (n. 15), pp. 93-95 y Barrientos (n. 16), p. 273. 
que al incorporar a las funciones de dichos tribunales un papel reparatorio, propio del Derecho Civil, se señalara la inconveniencia de dividir las acciones contravencionales y civiles dentro del mismo procedimiento. La posición que se critica se funda para Ruperto Pinochet en los ex artículos 8 y 9 de la ley $\mathrm{N}^{0} 18.223$, por los cuales la acción resarcitoria se podía entablar en el proceso infraccional de la dicha ley o fuera de él; pero para que el juez pueda conocer de la acción civil, debía interponerse en un proceso contravencional sujeto a condena infraccional ${ }^{23}$. Este argumento debe desecharse por cuanto los casos en que sólo se genere un perjuicio para el consumidor y no se dé lugar a la responsabilidad infraccional, no debería aplicarse la LPDC, lo que sería absurdo ${ }^{24}$.

b) La concepción misma del Derecho de Daños, que se sustenta en el principio de la reparación integral del daño, nos conduce a se pueda demandar exclusivamente en sede civil no infraccional y conforme a la normativa del Derecho del Consumo. Las conclusión contraria transgrediría el artículo 3, letra e) de la LPDC, que preceptúa:

"son derechos y deberes básicos del consumidor: e) El derecho a la reparación e indemnización adecuada y oportuna de todos los daños materiales y morales en caso de incumplimiento de cualquiera de las obligaciones contraídas por el proveedor, y el deber de accionar de acuerdo a los medios que la ley le franquea" ${ }^{25}$.

c) La ley $\mathrm{N}^{\mathrm{o}} 19.555$ modificó la letra $\mathrm{A}$, inciso $1^{\circ}$ e inciso $2^{\circ}$ del artículo 50 de la LPDC, otorgando competencia a los juzgados de policía local respecto de:

"todas las acciones que emanan de esta ley, siendo competente aquel que corresponda a la comuna en que se hubiere celebrado

${ }^{23}$ En este sentido dicha reforma sólo pretendió dejar en claro que se pueden entablar una acción civil -que emana tanto de la responsabilidad como de una acción contravencional por faltas; pero en caso que proceda la responsabilidad infraccional, ella traería aparejada responsabilidad civil.

${ }^{24}$ En este sentido Bruno Caprile señala: "la competencia del Juzgado de Policía Local fue notoriamente ampliada [se refiere a la ley $N^{0} 19.955$ ], en términos tales que [se] ya no cabe cuestionar su facultad de conocer de los 'actos o conductas que afecten el ejercicio de cualquiera de los derechos de los consumidores', comprendiéndose expresamente las acciones destinadas 'a obtener la debida indemnización de perjuicios o la reparación que corresponda'..." (lo destacado y entre paréntesis es mío). CAPRILE (n. 18), p. 571.

${ }^{25}$ Pinochet (n. 22), p. 438. 
el contrato respectivo, se hubiere cometido la infracción o dado inicio a su ejecución, a elección del actor",

y reconociendo una serie de remedios a favor del consumidor, en el inciso $2^{\circ}$, diferentes a la sanción infraccional. Para Juan I. Contardo esta modificación es de suma importancia porque distinguiría claramente entre acciones infraccionales y civiles al referirse a "todas las acciones", otorgando competencia al juez de Policía Local respecto de todas ellas ${ }^{26}$.

d) La responsabilidad infraccional y civil, que proviene de la transgresión a la LPDC, se diferencian en los sujetos y la cosa pedida. Lo que nos debe llevar necesariamente a separar las acciones y permitir que la acción civil se pueda entablar en un juicio civil, independiente o junto con la responsabilidad infraccional. Así, para José Luis Guerrero se trata de acciones diferentes e independientes, señalando:

"el Estado debe perseguir su propia pretensión, sin imponer tal carga a un consumidor que habiendo sufrido el perjuicio sólo pretende el resarcimiento íntegro y oportuno del daño sufrido" 27.

Una interesante sentencia de la Corte de Apelaciones de Concepción, de 5 de noviembre de 2009, rol ingreso $\mathrm{N}^{\circ} 231-09$, recoge las posiciones precedentes, resolviendo, en su considerando cuarto:

"al respecto, es necesario tener presente que el aludido artículo 26 [norma] establece un plazo pero sólo para el ejercicio de las acciones contravencionales (no para acciones civiles), contado desde que se haya incurrido en la infracción respectiva... Por este motivo procede rechazar la excepción de prescripción deducida por el demandado" 28 ,

${ }^{26}$ CAPRILE (n. 18), p. 571 y CONTARdo (n. 15), pp. 96-97. Estos argumentos se ven reforzados por lo establecido, en el artículo $50.1^{\circ}$ de la LPDC, dada la redacción que le dio la ley No 19.955 de 2004, por el cual "las acciones que derivan de esta ley, se ejercerán frente a actos o conductas que afecten el ejercicio de cualquiera de los derechos de los consumidores".

${ }^{27}$ José Luis Guerrero BeCAR, "La distinción entre contravención infraccional e incumplimiento contractual o contravención civil en materia de protección de derechos del consumidor", en Alejandro GuZMán BRito (coord.), Colección de estudios de Derecho Civil en homenaje a la profesora Inés Pardo de Carvallo, Valparaíso, Ediciones Universitarias de Valparaíso, 2008, p. 453.

${ }^{28}$ La sentencia de la CA confirmó un fallo del JPL de Talcahuano, de 18 de diciembre de 2008, en autos Norambuena Oliva con Empresas La Polar, rol No 350-D-08. 
por lo que el fallo distingue entre prescripción de acciones infraccionales, por una parte, y civiles, por la otra, (prescribiendo estas últimas de acuerdo a las reglas generales $)^{29}$. Sin perjuicio de lo anterior, la separación entre responsabilidad infraccional, a la que se refiere el artículo 26 de la LPDC, y la responsabilidad civil, que se rige por las normas del Código Civil, como hemos visto, aún no termina por imponerse del todo. Ello se debe a que, de acuerdo con la posición dominante en los tribunales, planteada en el apartado anterior, para poder interponer la acción civil se requiere de una condena infraccional en sede de Juzgado de Policía Local.

Sin perjuicio de lo anterior, la doctrina de Derecho se Consumo ha ido aún más lejos en torno a la restricción del ámbito de aplicación del artículo $26.1^{\circ}$ de la LPDC, y ha excluido de la aplicación del artículo no sólo a la responsabilidad civil sino a todas las acciones civiles que se desprenden de la regulación del consumo y no son consideradas como "exclusivamente" infraccionales. De este modo, Francisca Barrientos señala que la acción de nulidad, que proviene de las transgresión de las cláusulas abusivas, no prescribe conforme al artículo $26.1^{\circ}$ de la LPDC, sino conforme a las reglas generales de prescripción de la acción de nuli$\operatorname{dad}^{30}$. José L. Guerrero, en un lúcido trabajo, distingue tres estatutos que regirían el Derecho del Consumo. Así, en la LPDC existirían los siguientes estatutos regulatorios:

i) los que regulan las infracciones sin incumplimiento contractual;

ii) los que regulan el incumplimiento contractual no infraccional y

iii) los que regulan ambos estatutos, es decir, que regulan un incumplimiento contractual-infraccional (régimen mixto).

${ }^{29}$ Ruperto Pinochet y Juan I. Contardo señalan, a favor de esta posición aún minoritaria, a la cual se suman, los siguientes fallos: Arias Madariaga con Sodimac, Corte de Concepción 24 de diciembre de 2007, rol 174-2005, que es un caso de electrocución (se quemó) al tomar una lámpara y Vásquez con Patrol S.A., Corte de Apelaciones de Concepción, 28 de noviembre de 2008, rol No 66.186. Juan I. Contardo agrega a favor de la posición minoritaria, los votos disidentes de los ministros Jaime Rodríguez Espoz en Farías con West Store S.A. y Ripley Plaza Vespucio, Corte de Apelaciones de Santiago, 26 de diciembre del 2002, rol No 5437-2000. Contardo (n. 15), pp. 93-95 y Pinochet (n. 22), p. 429.

${ }^{30}$ De esta forma, Francisca Barrientos señala: "aquí, se aplica el plazo de los seis meses para todas las acciones sin distinción alguna. Me parece que el plazo de prescripción de la acción destinada a obtener la nulidad de la cláusula abusiva, al ser una acción civil es -por integración- de diez años contados desde la fecha de celebración del contrato. Otra cosa muy distinta es la sanción infraccional.

Es lamentable que este caso se haya confundido la aplicación de estos estatutos (se refiere al infraccional y el propio del Derecho Común). Aun cuando hay que reconocer que esto es una práctica arraigada en la jurisprudencia del consumo" (lo destacado entre paréntesis y en cursiva es mío). Barrientos (n. 16), p. 272. 
La primera situación, que distingue José L. Guerrero, se refiere a los casos en que el SERNAC puede actuar ejerciendo sus facultades controladoras ante tribunales, es decir, se trata claramente de una responsabilidad infraccional la cual se regiría -a nuestro entender- por el artículo $26.1^{\circ}$ de la LPDC. La mayoría de las facultades del SERNAC, contenidas en el título vi de la LPDC, tienen su origen en la responsabilidad contravencional y, por ende, obedecen a una función punitiva, sancionadora o preventiva. Para José L. Guerrero, las acciones que quedan comprendidas en el grupo infraccional serían las consignadas en los artículos $1, \mathrm{~N}^{\circ} 3.2^{\circ} ; 14 ; 16 ; 17 ; 20$, letras a) a c); 28, A; 28, B; 29; 30; 32; 35 y 37 de la LPDC, entre otros. La inclusión de las cláusulas abusivas (reguladas en el artículo 16 de la LPDC), en este estatuto, no está exenta de dudas. Ello, sin embargo, se ve ratificado por una sentencia de la CA de Santiago que ha resuelto que el plazo de prescripción para demandar por cláusulas abusivas se rige por el artículo $26.1^{\circ}$ de la $\mathrm{LPDC}^{31}$. En contra de esta posición se inclina Francisca Barrientos para la cual la acción de nulidad, que proviene de la imposición de una cláusula abusiva de las establecidas en el artículo 16 de la LPDC, se rige por las reglas generales de la nulidad ${ }^{32}$. La divergencia de resultados, a los que nos conduce el razonamiento de la dogmática de Derecho de Consumo y de los tribunales, nos lleva a plantearnos, ¿̇realmente la acción de nulidad -que proviene de la infracción a las reglas que regulan las cláusulas abusivas- no puede prescribir conforme al artículo $26.1^{\circ}$ de la LPDC?, o dicho de otra forma, ¿̇i el estatuto infraccional, a que se refiere el artículo 26 en estudio, no se puede aplicar a las infraccional a la LPDC que generan nulidad? ${ }^{33}$.

El segundo estatuto jurídico, al que se refiere José L. Guerrero, es el del incumplimiento sin infracción. Este estatuto estaría conformado básicamente por la responsabilidad común, como la que proviene de una venta de un producto en perfecto estado, pero que constituye un incumplimiento contractual. Como es natural, la prescripción de estas acciones se rige por el Derecho Común. Este supuesto debe diferenciarse de la acción civil que confluye con la responsabilidad infraccional ${ }^{34}$. Para

${ }^{31}$ Una sentencia de la Octava Sala de la CA de Santiago, 3 de octubre de 2011, rol $N^{\circ}$ 976-2011, resuelve en el sentido precedente es criticada por Francisca Barrientos. BARRientos (n. 16), pp. 267 y 271-274.

${ }^{32}$ Op. cit., p. 272.

${ }^{33}$ Para resolver estos problemas se suele recurrir al principio de protección del contratante débil. En este sentido Bruno Caprile nos señala, refiriéndose a una situación distinta, pero similar a la analizada, “...esa interpretación conduciría (...) a un resultado enojoso, como es privar de toda protección al consumidor que deja transcurrir el breve término de prescripción o de caducidad...”. CAPRILE (n. 18), p. 571.

${ }^{34}$ José L. Guerrero se refiere acá a un supuesto en el cual no ahonda, que es la posibilidad que el incumplimiento contractual, se configure conforme a la LPDC, pero excluya un supuesto infraccional. En otras palabras, esta tesis nos sugiere que pueden haber 
el autor, estos casos, de incumplimiento contractual sin infracción, serían los establecidos en el artículo 20 de la LPDC, con exclusión de las letras a) a c). En ellos, agrega:

"se debe permitir al consumidor ejercer la acción reparatoria, independientemente de la acción infraccional y aún, más sin ella” ${ }^{35}$.

En estos supuestos estaríamos en presencia de un "incumplimiento de obligaciones que derivan del contrato de consumo, pero que no constituyen una infracción" 36 . Este estatuto se rige por el ya aludido artículo 21 de la LPDC y en ningún caso por el artículo $26.1^{\circ}$ del mismo cuerpo legal. Por otra parte, estos supuestos estarían constituidos por incumplimientos estatutarios que dan lugar a supuestos de imputabilidad objetiva, configurados por la trasgresión de obligaciones legales, que se incorporan al contrato a través de la LPDC.

Finalmente, las situaciones mixtas, es decir, de infracción e incumplimiento, estarían contempladas en los artículos 3 bis. $4^{\mathrm{o}} ; 23.2^{\mathrm{o}} ; 25.2^{\mathrm{O}} ; 28$ y 45 de la LPDC y 5 de la ley $\mathrm{N}^{\mathrm{o}} 18.223^{37}$. En estas hipótesis mixtas para José L. Guerrero la responsabilidad infraccional y civil se separan y el consumidor no está obligado a recurrir por ambas de forma conjunta ${ }^{38}$.

Por consiguiente, como hemos podido analizar, parte de la doctrina de Derecho de Consumo distingue entre diferentes estatutos regulatorios, lo

transgresiones estatutarias, no infraccionales, como la estipulación de cláusulas abusivas, que no dan lugar a multas, y que nos llevan a aplicar el Derecho Común. Guerrero (n. 27), pp. 448-449.

${ }^{35}$ Guerrero (n. 27), p. 449.

${ }^{36}$ Para este autor la responsabilidad infraccional estaría dada exclusivamente por la aplicación de multas y excluiría cualquier pretensión reparatoria de la expectativa rota del acreedor.

En este sentido, el autor precedente señala que una falla de la cosa, durante el período de garantía, constituye un incumplimiento contractual que no da lugar a multas, y que, por ende, no es constitutivo de responsabilidad contravencional. Así, refiriéndose a esta situación, señala: "considero que más bien se trata de una infracción al contrato, de modo que no debe ser sancionado con multa y procede el ejercicio de los mecanismos de reparación y de remedio que derivan del contrato de consumo".

Sin embargo, su conclusión es apresurada por cuanto la responsabilidad infraccional -que parte de la doctrina la circunscribe a las multas- tiene una función preventiva. Por ello, algunos casos de garantías no respetadas por el productor naturalmente podrían generar multas, sobre todo si se aplica el artículo 25 de la LPDC. Guerrero (n. 27), p. 448.

${ }^{37}$ Guerrero (n. 27), pp. 442-453.

${ }^{38}$ Así, José L. Guerrero parece inclinarse por la posibilidad de que el consumidor pueda interponer, por una parte una denuncia o querella infraccional ante el respectivo Juzgado de Policía Local y, por la otra, una acción civil ante los mismos juzgados (el autor es de la opinión que estas acciones deberán oponerse ante el Juzgado de Policía Local). Guerrero (n. 27), p. 453. 
que incidirá en la exclusión de la aplicación del artículo 26 de la LPDC, y en una serie de aspectos que escapan al presente trabajo ${ }^{39}$.

c. La posición intermedia de Hernán Corral:

la infracción a la regulación de la LPDC

puede configurar un ilícito civil, que debe

calificarse por el Juzgado de Letras

en lo Civil "in concreto"

Una posición intermedia, con relación a las dos posiciones anteriores, adopta Hernán Corral. Para el referido autor, la acción civil, en la medida que, a su vez, de lugar a una responsabilidad extracontractual, se podrá presentar como ordinaria, aun después de transcurrido el plazo de prescripción de los seis meses ${ }^{40}$. Pero el ilícito civil se regiría enteramente por las reglas de la responsabilidad extracontractual. Lo relevante de esta posición es que la infracción, a las reglas del Derecho del Consumo, no podrá ser valorada per se como un ilícito civil por el juez de letras. Así, contrario sensu, la transgresión estatutaria podría ser calificada por el juez como un ilícito civil de los que da lugar a la responsabilidad extracontractual ${ }^{41}$.

Esta posición es eminentemente práctica y sigue la tendencia a interpretar estos estatutos a favor del contratante débil. Sin embargo, esta tesis no está exento de críticas, desde que en la medida que la acción sea contractual, el acreedor no podrá recurrir al estatuto de la responsabilidad extracontractual. Ello, sin perjuicio que se entienda que estos casos dan lugar a lo que malamente se ha denominado como cúmulo de responsabilidades ${ }^{42}$.

${ }^{39}$ En este sentido, José L. Guerrero señala: “una reordenación de las contravenciones que contempla la Ley de protección al consumidor en las tres categorías contravencionales propuestas permitirá alcanzar hacia una adecuada protección de los derechos de los consumidores: perfeccionaría la tutela jurisdiccional distinguiendo acción, legitimario activo, competencia y procedimiento; la prescripción podrá operar conforme a la naturaleza de la acción correspondiente...”. GuerRero (n. 27), p. 453.

${ }^{40} \mathrm{Al}$ respecto de forma muy clara Hernán Corral nos señala: "la acción civil podría plantearse ante los Tribunales Ordinarios, pero ahora fundada en los arts. 2314 y siguientes del Código Civil y no estrictamente en la conducta infraccional, cuya sanción no es de competencia de los jueces ordinarios". Hernán Corral Talciani, Responsabilidad por productos defectuosos, Santiago, Abeledo Perrot, LegalPublishing, 2011, p. 129.

${ }^{41}$ En este sentido para Hernán Corral la prescripción de la acción por responsabilidad civil -derivada del ilícito infraccional del artículo 23 de la LPDC- no se rige por el plazo de prescripción del artículo $26.1^{\circ}$ de dicha ley. Así, señala: "nada dice la ley sobre la prescripción de la acción civil para pedir indemnización de perjuicios por dicha infracción". Corral (n. 40), p. 128.

${ }^{42}$ De este modo, la transgresión a las reglas, contenidas en la LPDC, infraccionales o no e independientemente de la existencia de un contrato-, darían lugar a un ilícito civil propio de la responsabilidad extracontractual. 


\section{Regla especial en cuanto al plazo extintivo} de la responsabilidad por productos defectuosos

El artículo 26 de la LPDC no es aplicable a la responsabilidad por productos defectuosos (artículos $21.1^{\circ}, 7^{\circ}$ y $8^{\circ}$ y 23 de la ley) ${ }^{43}$. El artículo $21.1^{\circ}$ dispone que el ejercicio de los derechos, que contemplan los artículos 19 y 20, todos de la LPDC, es decir, los que se refieren a la garantía legal, deberán hacerse efectivos dentro del plazo de tres meses siguientes a la fecha en que se haya recibido el producto. De este modo, el artículo $21.1^{\circ}$ de la LPDC dispone:

"el ejercicio de los derechos que contemplan los artículos 19 y 20 (estos artículos se refieren a la responsabilidad por incumplimiento de la garantía legal) deberá hacerse efectivo ante el vendedor dentro de los tres meses siguientes a la fecha en que se haya recibido el producto, siempre que éste no se hubiere deteriorado por hecho imputable al consumidor. Si el producto se hubiere vendido con determinada garantía, prevalecerá el plazo por el cual ésta se extendió, si fuere mayor" (lo destacado entre paréntesis es mío ${ }^{44}$.

${ }^{43}$ Los incisos citados son del siguiente tenor:

"Art. $21.1^{\circ} \mathrm{El}$ ejercicio de los derechos que contemplan los artículos 19 y 20 deberá hacerse efectivo ante el vendedor dentro de los tres meses siguientes a la fecha en que se haya recibido el producto, siempre que éste no se hubiere deteriorado por hecho imputable al consumidor. Si el producto se hubiere vendido con determinada garantía, prevalecerá el plazo por el cual ésta se extendió, si fuere mayor.

$7^{\circ}$ En el caso de productos perecibles o que por su naturaleza estén destinados a ser usados o consumidos en plazos breves, el término a que se refiere el inciso primero será el impreso en el producto o su envoltorio o, en su defecto, el término máximo de siete días.

$8^{\circ} \mathrm{El}$ plazo que la póliza de garantía otorgada por el proveedor contemple y aquel a que se refiere el inciso primero de este artículo, se suspenderán durante el tiempo en que el bien esté siendo reparado en ejercicio de la garantía".

${ }^{44}$ En el proyecto original del Ejecutivo de la LPDC, la regulación de este plazo extintivo especial estaba contenida, en el artículo 15, en los siguientes términos: "la reclamación del derecho de opción que contemplan los artículos 13 y 14 podrá hacerse efectiva indistintamente en contra del vendedor, el fabricante o el importador, dentro de los tres meses siguientes a la fecha en que se haya recibido el producto, siempre que éste no se hubiere deteriorado por descuido del consumidor. Si el producto se hubiere vendido con determinada garantía, prevalecerá el plazo por el cual ésta se extendió, si fuere mayor.

En el caso de productos que por su naturaleza están destinados a ser consumidos de inmediato, el plazo a que se refiere el inciso anterior será de treinta días.

Tratándose de la devolución de la cantidad pagada, el plazo para ejercer la acción se contará desde la fecha de la correspondiente factura o boleta, y no podrá intentarse sino respecto del vendedor.

Para ejercer estas acciones el consumidor deberá acreditar el acto o contrato con la documentación respectiva". 
Esta última regulación disciplina la responsabilidad por productos defectuosos. A este respecto, la doctrina había distinguido entre responsabilidad por incumplimiento contractual (a la que se refiere el artículo 21 de

La norma precedente fue transformada mediante una indicación del Ejecutivo por la cual se modificaba el inciso primero de la disposición precedente, siendo del siguiente tenor: "el ejercicio de los derechos que contemplan los artículos 16 y 17 deberá hacerse efectivo ante el vendedor dentro de los tres meses siguientes a la fecha en que se haya recibido el producto, siempre que éste no se hubiere deteriorado por descuido del consumidor. Si el producto se hubiere vendido con determinada garantía, prevalecerá el plazo por el cual ésta se extendió, si fuera mayor. Tratándose de la venta de bienes inmuebles a que se refiere el inciso segundo del artículo $2^{\circ}$, el plazo para ejercer estos derechos será de un año, contado desde la entrega del bien”. La Comisión de Economía, a instancias del senador Francisco Prat, acordó eliminar la referencia a los bienes inmuebles, y sustituir la expresión 'descuido del' por 'hecho imputable al', por estimar que de otra forma podría interpretarse como una excepción relacionada exclusivamente con culpa o negligencia. A su vez, se adecuó la referencia a los artículos 16 y 17, por otra a los artículos 15 y 16 .

El director nacional del SERNAC de la época, señor Francisco Fernández, durante la discusión del proyecto de ley, indica: “...estimamos que algunos aspectos particularmente importantes de la protección al adquirente de vivienda nueva hacen aconsejable que el marco regulatorio que consagre esta futura ley sobre derechos de los consumidores sea aplicable a ese caso preciso de operación de consumo recaída en inmuebles. Esto dice relación a dos aspectos. El primero es el de la garantía legal que este cuerpo normativo establecerá en relación con vicios ocultos de la cosa vendida, en lo cual innova respecto al ejercicio de la acción redhibitoria prevista en el Código Civil, especialmente en cuanto al derecho del comprador que ejerce la acción redhibitoria por vicios ocultos, derecho que, como los señores Senadores recordarán, en el caso del Código Civil se traduce en la acción para dejar sin efecto el contrato o para obtener reducción del precio cuando ese vicio demerita considerablemente el valor de la cosa vendida, en términos tales que, de haber conocido el comprador esos vicios, no habría celebrado el contrato o habría pagado menor precio por la cosa. Acá se abre la posibilidad de la reparación gratuita dentro de cierto lapso cuando estos defectos o vicios se ponen de manifiesto, lapso que, en el caso de los bienes muebles, es de tres meses. Respecto de los inmuebles, en el transcurso del primer año surgirá la acción de resarcimiento en términos de reparación gratuita o la acción encaminada a dejar sin efecto el contrato, lo que es consecuencia natural de una acción de esta índole. Tal acción ya no sería de cambio, como ocurre en el caso de los bienes muebles, porque, evidentemente, como los inmuebles son cosas no fungibles, es imposible, por ejemplo, cambiar un departamento por otro. Pero interesa sobremanera que se pueda invocar esta garantía legal mínima, porque también existe una diferencia muy importante respecto de la regulación de la acción redhibitoria en el Código Civil, el que, como los señores Senadores recordarán, supone que el comprador le pruebe culpa al vendedor respecto del vicio oculto, es decir, le pruebe que ha conocido o debido conocer ese vicio y no lo ha declarado al momento de celebrar el contrato.

Tratándose de esta garantía legal que consagra la Ley del Consumidor, siguiendo en esto la orientación prevaleciente en el derecho comparado, respecto de ese tipo de defecto en una operación de consumo, basta probar el defecto y su entidad, y la relación de causa-efecto entre la acción u omisión del vendedor y el defecto en sí, sin necesidad de probar la culpa, que será una cuestión por dilucidar entre la empresa inmobiliaria vendedora y la empresa constructora encargada de la edificación. Ésta es la dimensión tutelar o protectora que tiene la acción de garantía en el derecho del consumidor. 
la LPDC), que es consecuencia de la transgresión de una garantía legal o propiamente contractual, por una parte, o de una responsabilidad derivada de ilícito infraccional, por la otra. Por ello, la prescripción de la responsabilidad por transgresión de garantía estaría regulada en el artículo 21 de la ley y de la indemnizatoria por violación estatutaria estaría regulada en el artículo 26. Esta distinción es la que efectúa Hernán Corral, antes de la promulgación de la ley $\mathrm{N}^{\mathrm{o}} 20.555$. Y ella se mantendría en la actualidad y podría aplicarse a la responsabilidad infraccional, distinguiéndose entre responsabilidad por incumplimiento contractual y responsabilidad extracontractual civil o responsabilidad estatutaria contenida en la ley y no en el contrato ${ }^{45}$. Además,

Por eso, entendemos que, sin desmedro de las estipulaciones contractuales pertinentes, pueda operar esta garantía básica tratándose de defectos o vicios ocultos.

Además, lo concerniente a las normas sobre publicidad engañosa que esta ley por primera vez introducirá en forma amplia en nuestro ordenamiento jurídico, también es importante, porque suele haber, en relación con la comercialización de inmuebles nuevos, anuncios publicitarios y promesas, referentes a cualidades o atributos de los bienes, que luego no se cumplen. Entonces, el poder ejercer, a propósito de ese tipo de actividades, la acción respectiva para el cumplimiento de aquellas promesas o afirmaciones, sólo será posible en la medida en que ello quede recogido en esta ley, lo que naturalmente será de aplicación supletoria, es decir, sólo en defecto de norma expresa distinta en la otra 136 ley. Porque, si bien con razón recordaba ayer el Senador señor Thayer que se aplica en materia de hermenéutica legal el principio de que la ley posterior deroga la anterior en lo que difieran, no es menos cierto que también se aplica el principio de la 'especialidad', conforme al cual la norma especial prevalece sobre la general en cualquier evento". Sin perjuicio de lo señalado por el ex Ministro, en definitiva, se excluyó la referencia a la construcción y las viviendas contenida en el proyecto de ley por estimarse que esta materia se debía regular en materia de construcción y no en un juicio de consumo. De esta forma, el senador Miguel Otero resume el rechazo a la indicación del Ejecutivo de la siguiente forma: "en primer término, deseo recordar que ayer se acordó en la Sala eliminar la frase final del inciso cuarto del artículo $2^{\circ}$ del proyecto 'salvo en las materias que éstas ultimas no prevean', quedando como sigue: 'Con todo las normas de esta ley no serán aplicables a las actividades de producción, fabricación, importación, construcción, distribución y comercialización de bienes o de prestación de servicios reguladas por leyes especiales'. Ses 37-03.

Por lo tanto, de aprobarse la indicación, nos encontraríamos con una contradicción evidente, porque por un lado se estipula que las disposiciones de la ley se aplican a materias relacionadas con la construcción y la vivienda, y a continuación en el último inciso se establece expresamente que no es así. Por consiguiente, habría un error legislativo bastante serio, y nadie podría entender que en un mismo artículo el Senado apruebe dos ideas absolutamente contrapuestas". Véase Historia de la Ley No 19.496, año en www.leychile. cl/Consulta/portada_hl, pp. 457 y 707. Consultada el 6 de julio de 2012.

${ }^{45}$ En este sentido Hernán Corral señala: "la responsabilidad civil derivada de un ilícito infraccional se asemeja a la responsabilidad civil que surge de la responsabilidad penal. Si la conducta constitutiva de la infracción genera un daño, surge una doble acción: una para hacer efectiva la responsabilidad infraccional y otra para pedir el resarcimiento del perjuicio causado, es decir, la responsabilidad civil. 
de la responsabilidad por productos defectuosos, la ley $\mathrm{N}^{\mathrm{o}} 20.423$, de 12 de febrero de 2010, establece una regulación diferente para la prescripción extintiva, que la establecida en la LPDC. En este sentido, en el párrafo $9^{\circ}$ de la ley, titulado "de la protección al turista. Infracciones y sanciones", se establece que un plazo de dos años, desde que se comete la infracción; pero agrega en su inciso $2^{\circ}$ :

"sin perjuicio de lo dispuesto en el artículo 24 de la ley precitada, para la aplicación de las multas el tribunal tendrá especialmente en cuenta la situación de indefensión en que hubiere quedado el turista con motivo de la infracción, la facilidad en el acceso a la información de los servicios ofrecidos y los daños efectivamente causados o el riesgo generado. Podrá considerar, además, el idioma del turista, su tiempo de permanencia en el país y la circunstancia de haber o no contratado con una agencia de turismo" ${ }^{46}$.

Para finalizar se ha entendido que el plazo de garantía legal es de caducidad y no de prescripción extintiva. En este sentido, Francisco Fernández señala:

"la garantía legal está sujeta a caducidad pues debe hacerse efectiva dentro de los plazos que la ley fija en cada caso (bienes duraderos, bienes de consumo inmediato o servicios) y la voluntaria, en el término señalado en la póliza" ${ }^{47}$.

Se trata, por tanto, de una responsabilidad extracontractual, ya que no supone el incumplimiento de un contrato sino la violación de un deber legal”. El referido autor, más adelante, agrega que esta responsabilidad se desprende de las conductas infraccionales que la LPDC establece, de dos formas: una literal, en consideración a la cual la LPDC se refiere a "las infracciones a lo dispuesto en la ley", y otra de fondo, que se reconoce por el establecimiento de multas. CORRAL (n. 40), pp. 125-126.

El tema, sin embargo, nos parece complejo desde que la responsabilidad estatutaria -no infraccional- proviene de la violación del estatuto normativo, que comprende normas contractuales, provenientes de condiciones generales y también de la ley. Además, este tema está íntimamente relacionado con los problemas de concurrencia de responsabilidad. María Teresa Alonso Traviesa, El problema de la concurrencia de responsabilidades, Santiago, Lexis Nexis, 2006, pp. 388-556.

${ }^{46}$ La ley $\mathrm{N}^{\circ} 20.423$, de 12 de febrero de 2010, en su artículo $49.1^{\circ}$ establece: "las infracciones a la calidad y/o seguridad de los bienes y servicios vendidos o prestados; a la información y publicidad entregada a los turistas; al trato dado a los mismos; y, en general, cualquier otra en materia de consumo, serán sancionadas en los términos establecidos en la ley $\mathrm{N}^{\circ} 19.496$, sobre Protección de los Derechos de los Consumidores".

${ }^{47}$ Fernández (n. 1), pp. 42-43. 


\section{Algunas consideraciones en torno a la caducidad}

El inciso tercero del artículo 26 de la LPDC establece un plazo extintivo de caducidad de un año, que se aplica a "las sanciones impuestas por dichas contravenciones" (se refiere a las impuestas en virtud del inciso primero de la misma norma).

Estos plazos por regla general no admiten interrupción ni suspensión. Pero como ha puesto en relieve Osvaldo Lagos, la caducidad sobre derechos disponibles admitiría la suspensión. La suspensión sería, a este respecto, la imposibilidad en que se encuentra el acreedor de ejecutar el derecho dentro de plazo que le concede la ley. En este sentido, a pesar de lo preceptuado en el inciso $2^{\circ}$ de la norma en estudio, se podría admitir la suspensión de la caducidad ${ }^{48}$.

Los plazos precedentes, de prescripción (artículo $26.1^{\circ}$ de la LPDC) y caducidad (artículo $26.3^{\circ}$ de la LPDC), son muy reducidos, sobre todo si se les compara con los plazos de las acciones de consumo en el Derecho Comparado, que suelen ser de tres y diez años, respectivamente ${ }^{49}$. Por otra parte, lo más llamativo de la regulación chilena, es la tenencia a la aplicación restrictiva de la normativa que regula la responsabilidad infraccional. Ello se refleja, como hemos visto, en la exclusión de las reglas de responsabilidad infraccional a la responsabilidad civil del consumo. 138 Ella debería comprender ambas responsabilidades. Por ello el fallo de la Corte de Apelaciones -que sostiene que el artículo 26.1 ${ }^{\circ}$ de la LPDC es de aplicación general-, no debe sorprendernos, ante lo absurdo a que nos conduce el que la LPDC simplemente haya omitido la regulación de la prescripción y caducidad de la acción civil.

\section{DUdAS QUE GENERA LA REgULACIÓN DE LA PRESCRIPCIÓN EXTINTIVA EN LA LPDC}

La regulación que hace la LPDC, respecto de la prescripción extintiva, no responde una serie de preguntas fundamentales, como son las siguientes: ¿desde cuando se cuenta el plazo de prescripción?, ¿̇es modificable el plazo de prescripción?, ¿`se interrumpe o se suspende la prescripción del artículo 26 de la LPDC, conforme a las reglas del Código Civil?, etc. A

${ }^{48}$ Naturalmente estaríamos en presencia de un derecho disponible, como lo es la sentencia infraccional que establece un derecho de crédito a favor del consumidor. LAGOS (n. 2), p. 103.

${ }^{49}$ Los artículos 14:201 de los PECL y III-7:201 de la DCFR establecen un plazo general de prescripción de tres años, y de caducidad de diez años para las acciones declaradas por sentencia, laudo arbitral, u otro título similar en tanto en cuanto sea ejecutivo en los mismos términos que una sentencia (artículos 14:202 del PECL y III-7:202 de la DCFR). 
continuación, trataré de responder estas preguntas, no olvidando la posición sostenida por nuestros tribunales -aunque no de forma unánime-, conforme a la cual la prescripción y caducidad, de la acción infraccional, trae aparejada la imposibilidad de entablar la acción civil. Por ello, las soluciones que se establecen para los efectos de la función contravencional pueden repercutir en la acción civil.

\section{Regulación que determina desde cuándo se cuenta el plazo de prescripción}

La determinación desde cuando se cuenta el plazo de prescripción depende básicamente de la posición que se adopte en torno la relación entre la responsabilidad infraccional y civil. De este modo, conforme a la posición jurisprudencial mayoritaria, lo relevante será la responsabilidad infraccional y en la mayoría de los casos la prescripción de la acción infraccional traerá aparejada la caducidad de la acción civil. Ello sin perjuicio que la acción civil podría prescribir de forma independiente. A su vez, la posición minoritaria nos lleva a distinguir entre responsabilidad infraccional y responsabilidad civil contractual y extracontractual.

a. Determinación desde cuándo se cuenta la prescripción de la acción infraccional

El plazo de prescripción, establecido por la LPDC, conforme al artículo $26.1^{\circ}$ de la misma ley, se cuenta desde que "se haya incurrido en la infracción respectiva" ${ }^{50}$. En este sentido, conforme a una primera interpretación de la norma, se puede entender que se recurre a un criterio objetivo de cómputo del plazo de prescripción, desde que se prescinde del conocimiento de la infracción, que pudo tener el acreedor. Lo que nos lleva a preguntarnos si la infracción se produce en un proceso de fabricación o de venta, la prescripción se debe contar desde dichos momentos, a pesar de que el consumidor aún no ha adquirido nada o que el

${ }^{50}$ El establecimiento de este criterio para comenzar a contar el plazo de la prescripción extintiva no se condice con lo preceptuado en los artículos 14:203 del PECL y III-7:203 de la DCFR. En dichos instrumentos, el plazo de prescripción se cuenta desde que la obligación se hizo exigible, lo que dependerá de la naturaleza de la pretensión en la medida que tengan un origen diferente. De este modo, la pretensión de cumplimiento se hace exigible al suscribirse la obligación; en cambio la indemnizatoria exige que se produzca el daño. Finalmente, en los casos de prescripción de las acciones que emanen de acciones declaradas por sentencia, laudo arbitral, u otro título similar -en cuanto sea ejecutivo en los mismos términos que una sentencia, de acuerdo con los artículos 14:203 PECL y III-7:203 de la DCFR- el plazo de prescripción se cuenta desde que la sentencia o el laudo arbitral adquieren efectos de cosa juzgada. En estos casos el plazo es de diez años. 
daño o el conocimiento de la infracción por parte del consumidor se haya generado en forma posterior. De ser de este modo, la acción infraccional pudo haber nacido prescrita, lo cual se debe desechar por absurdo ${ }^{51}$. Lamentablemente, éste es el razonamiento seguido por la sentencia del $3^{\text {er }}$ Juzgado de Policía Local, de fecha 13 de enero de 2011, que se pronuncia respecto de la venta de alimentos en mal estado. La prescripción de la acción infraccional, conforme a dicha sentencia, se cuenta desde la venta de los alimentos por aplicación del artículo 23 de la LPDC ${ }^{52}$. Ello, por lo claro, es un error, por cuanto, como hemos visto, la prescripción afecta la acción infraccional y ella sólo puede ejercerse, en el caso precedente, desde que se conoce la infracción, es decir, en este caso desde que el consumidor tuvo acceso al informe toxicológico. Lo contrario vendría a significar que el artículo $26.1^{\circ}$ de la LPDC establece un plazo de caducidad y no de prescripción ${ }^{53}$. Lo anterior lleva a sostener una segunda interpretación por la cual "la infracción respectiva" exige la concurrencia de todos lo elementos de la responsabilidad infraccional, como la determinación, tanto del sujeto pasivo como del activo. Esta interpretación, a diferencia de la que se critica, es consistente con las diferencias que se han puesto de relieve entre la prescripción extintiva y el decaimiento o caducidad del derecho.

140 La redacción de la norma precedente es lamentable, no sólo por los absurdos a que lleva su interpretación literal o mosaica sino porque este problema ya se había presentado en materia de responsabilidad extracontractual -a raíz de la redacción dada por el Código de Andrés Bello al ar-

${ }^{51}$ No nos olvidemos que conforme a una cantidad muy relevante de fallos, de estar prescrita la acción infraccional, no se puede entablar la acción civil.

${ }^{52}$ La recurrente señaló que adquiere un arroz Miraflores, envasado por Carozzi, en el Supermercado Alvi S.A. Una vez que el consumidor abre uno de los paquetes encuentra que tiene gusanos. Analizado éstos por la Secretaria Ministerial de Salud, mediante un análisis microbiológico, resulta que tiene Rto. Escherichia coli; Rto. Staphylococus Aureus; P/A Salmonella en 25 gr. Ausencia, Rto. Bacillis Cereus. La prescripción para el tribunal se cuenta desde la venta y no desde el conocimiento del informe, lo que la lleva a acoger la excepción de prescripción y resolver, en el considerando cuarto de la sentencia, que “....esta sentenciadora acogerá la excepción de prescripción, por cuanto, en virtud a lo dispuesto en el artículo 23 de la Ley de Protección a los derechos de los consumidores (se cita la norma), norma legal que se aplica en la especie, ya que el acto de consumo es precisamente la venta de un producto. De esta manera, el plazo para interponer las acciones pertinentes, comenzará a corres desde el momento de la celebración del acto o contrato, mediante el cual la demandante adquirió el bien que se encontraba en condiciones deficientes, y a partir de este razonamiento el plazo exigido por el artículo 26 ya citado, se encontraba cumplido y en exceso al momento de deducirse la acción materia de autos..." (lo señalado entre paréntesis y en cursiva es mío).

${ }^{53}$ Sin perjuicio de este fallo, la Corte Suprema en ocasiones ha seguido el razonamiento inverso. 
tículo 2332-54. Como esta norma cuenta el plazo de prescripción "desde la perpetración del acto", una parte de la doctrina y unas sentencias de los tribunales de justicia contaron la prescripción desde la ocurrencia del hecho ilícito y no desde que concurren todos los presupuestos que exige la pretensión indemnizatoria ${ }^{55}$. Afortunadamente, esta posición fue criticada por nuestra doctrina, por cuanto, en algunos casos, la acción nacía prescrita, como sucedía cuando el daño se generaba transcurrido el plazo de prescripción de cuatro años. Lo que, por lo demás, no es extraño que acontezca en materia de responsabilidad médica. La prescripción de la acción, como destaca Enrique Barros siguiendo en ello a Robert Pothier, no puede contarse, sino desde que ella está disponible para el acreedor ${ }^{56}$. La perpetración del acto, por tanto, no se refiere sólo al ilícito o a un acto meramente infraccional sino a la concurrencia de todos los presupuestos que dan lugar tanto a la responsabilidad civil, como a la responsabilidad infraccional ${ }^{57}$. El que concurran todos los requisitos que la ley exige para

${ }^{54}$ Por otra parte, como destaca Ramón Domínguez Águila, Andrés Bello en el Código Inédito contaba el plazo de prescripción desde que se tuvo conocimiento del daño o dolo, siguiendo en ello a las Siete Partidas, la opinión más autorizada de la doctrina española y el Código de Florencio García Goyena. Un problema similar al chileno se producía en la legislación francesa -que fue modificada- y en la italiana (el artículo 2947 contaba el plazo desde el día en que el hecho se ha verificado). Domínguez Águila (n. 2), pp. 365-366.

${ }^{55}$ Para Arturo Alessandri R. en los casos que el daño y el ilícito se deferían en el tiempo la prescripción se debía contar desde la perpetración del acto. En este sentido, señalaba que la prescripción, en nuestro Derecho, debe contarse "desde el día en que se cometió el hecho doloso o culpable y no desde aquel que se produjo el daño, si éste y el hecho no son coetáneos".

${ }^{56}$ En igual sentido se puede consultar a Ramón Domínguez A. para el cual la posición de Arturo Alessandri es simplemente absurda y no tiene ningún asidero legal, ni histórico. En materia de responsabilidad extracontractual no se puede separara el ilícito del daño, como tampoco en la responsabilidad infraccional puede separarse la infracción del supuesto fáctico que le da origen. Ello se debe a que sólo desde que se verifica y, por ende, se tiene conocimiento de la infracción se genera una infracción que puede dar origen a la responsabilidad contravencional. Así, Ramón Domínguez A. señala: “no existe un 'acto' separado de su 'ilicitud' y ésta sólo existe si hay daño, de modo que una conducta podrá ser peligrosa; pero si el daño no se produce, no se ha 'perpetrado' ningún acto ilícito, ya que en materia de responsabilidad civil, al no existir el elemento de la tipicidad, propio del delito penal, sólo se da el hecho ilícito desde que éste sea dañoso”. Domínguez ÁGuila (n. 2), pp. 375-382.

${ }^{57}$ Enrique Barros Bourie, Tratado de responsabilidad extracontractual, Santiago, Editorial Jurídica de Chile, 2006, pp. 922-924.

Sin perjuicio de lo anterior, el TS español, a pesar de que el artículo $1968.2^{\circ}$ del $C C E$ establece un criterio subjetivo para la determinación del plazo de prescripción de la acción civil, en materia de responsabilidad extracontractual, ha resuelto que en los casos en que no es posible determinar al victimario se entiende que el plazo de prescripción corre contra la víctima, véase STS, 22 de marzo 1971. L. Fernando Reglero critica esta posición del TS. Reglero Campos (n. 8), p. 164. 
el ejercicio de la pretensión, por parte del acreedor, es el supuesto básico para que proceda la prescripción extintiva, a diferencia de lo que ocurre con la caducidad ${ }^{58}$. Por lo anterior, el entender que la prescripción se cuenta desde "el mero acto infraccional", establecería un inadmisiblemente exiguo plazo de caducidad, y confundiría el ámbito temporal de la infracción con la responsabilidad contravencional. El análisis precedente es todavía más relevante si se entiende, como lo hace la mayoría de los fallos de tribunales, que la acción civil depende de la acción infraccional o contravencional. Afortunadamente, se ha ido imponiendo en los últimos años una importante jurisprudencia por la cual la infracción se cuenta desde que ella es conocida por el consumidor o el SERNAC en su caso. Juan I. Contardo señala una interesante jurisprudencia de tribunales por la cual el inicio del plazo de prescripción se cuenta desde el conocimiento por parte del deudor del acto infraccional ${ }^{59}$.

${ }^{58}$ Uno de los autores que modernamente ha tratado mejor este tema es Fabián Elorriaga, que indica las siguientes razones a favor de la posición de la mayoría de la doctrina civil moderna -que desecha la posición de Arturo Alessandri-: (a) La prescripción solo puede correr desde que se cumplen con los requisitos, que exige la responsabilidad civil, para entablar la acción; (b) la interpretación contraria conduce al absurdo; (c) a lo imposible nadie está obligado; (d) la historia fidedigna de la norma lleva a la conclusión 142 opuesta a la sostenida por Arturo Alessandri; (e) las reglas de interpretación conducen a que para que corra la prescripción del artículo 2332 del CCCh debe existir un perjuicio indemnizable; (f) una interpretación armónica de esta norma y otras que generan el mismo problema (como sucede en los accidentes del trabajo y enfermedades profesionales por aplicación del artículo 79 de la ley $\mathrm{N}^{0} 16.744$; daños por uso de plaguicidas por aplicación de los artículos 8 y 36 del DL N ${ }^{0} 3.557$ de 1980 y daño al ambiente por aplicación del artículo 63 de la ley $\mathrm{N}^{\mathrm{o}} 19.300$ ); (g) las reglas de prescripción deben interpretarse de forma restringida; la prescripción sólo se puede contar desde que haya inactividad del acreedor; (h) la jurisprudencia italiana y argentina llega a la misma conclusión y (i) las normas de Derecho Comparado recogen este principio. A este respecto Fabián Elorriaga cita los artículos 310, § 1 del $C C$ holandés, 2925 del $C C$ de Quebec de 1994, 1968, № 2 del $C C$ español y $\S 852.1^{\circ}$ del $B G B$. Fabián Elorriaga De Bonis, "Del día de inicio del plazo de prescripción de una acción indemnizatoria cuando el perjuicio se ha manifestado con posterioridad al hecho que lo origina”, en Cuadernos de Extensión Jurídica, № 21, Santiago, Universidad de los Andes, 2011, pp. 42-54.

${ }^{59}$ Así, Juan I, Contardo se refiere a varios fallos que exigen el conocimiento de la infracción por parte del consumidor para los efectos que comience a corre el plazo de prescripción, resolviéndose que la infracción se comente desde que la publicidad logra el cometido de inducir al consumidor a contratar: sentencias de la CA de San Miguel, 31 de enero de 2009, rol No 1141-2008, en autos SERNAC con Universidad de Ciencias de la Información y CA de Santiago, 14 de agosto de 2009, rol No 8424-2009, en autos Silva con Corporación Educacional Universidad del Mar; desde que se sabe por el consumidor que la carrera no estaba acreditada y no desde la matrícula: sentencia de la CA de Santiago de 24 de marzo de 2010, rol No 179-2010, autos caratulados SERNAC con Universidad del Pacífico; desde la toma de conocimiento por parte del consumidor de que está en DICOM y no desde el envío a DICOM: sentencia de la CA de Santiago, de 12 de mayo 
En resumidas cuentas, en la prescripción extintiva lo que se extingue es una acción o pretensión, por lo que la acción o la pretensión debe haber nacido en manos del sujeto activo. Así, la "infracción respectiva" sólo se produce desde que se puede entablar o ejercer la respectiva acción o pretensión, lo que incluye para algunos la acción civil. No sucede lo mismo en cuanto a la caducidad, que extingue la facultad para ejercer una potestad. Por ello los plazos de prescripción extintiva son más breves que los de caducidad. En razón de las consideraciones precedentes, y a pesar del tenor literal de la norma, no se puede descartar recurrir a criterios subjetivos, como el conocimiento que adquiere el acreedor del acto infraccional, y contar el plazo de prescripción sólo desde la concurrencia de todos los requisitos que la acción o pretensión infraccional y netamente civil exigen. La Corte Suprema ha estimado por motivos diferentes que la prescripción exige, de parte del denunciante, el conocimiento de la infracción ${ }^{60}$. También se ha

de 2009, rol No 19.497 , en autos SERNAC con Chilectra S.A.; desde que el consumidor debió haber tomado conocimiento de los cargos mal efectuados en su cuenta de crédito: sentencia del $3^{\text {er }}$ JPL de Santiago, de fecha 12 de enero de 2007, rol N 9936-06 en autos SERNAC y otro con Santander Banefe y desde el último requerimiento extrajudicial de cobro de una deuda inexistente: sentencia del $1^{\text {er }}$ JPL de Puerto Montt, de 23 de enero de 2007, rol No 4956-2006, en autos caratulados García con Home Center Sodimac.

Sin perjuicio de lo cual, Juan I. Contardo señala una jurisprudencia minoritaria que cuenta la prescripción desde la fecha de celebración del contrato.Contardo (n. 15), pp. 99-102.

${ }^{60}$ A este respecto se pueden consultar las siguientes dos sentencias de la Corte Suprema: el fallo de la CS, de 1 de septiembre de 2009, Ing. No $5.858-2009$, pronunciado en los autos Silva Arévalo con Corporación Educacional Universidad del Mar, por el que se declara inadmisible la queja interpuesta contra una sentencia de la CA de Santiago, de fecha 14 de agosto de 2009, Ing. N ${ }^{\mathrm{O}} 8.424-2009$, que, a su vez, confirma la sentencia del $2^{\circ}$ JPL de Maipú, de fecha 27 de junio de 2009, rol No 3.809-2008 y el fallo de la CS de 26 de enero de 2011, Ing. $\mathrm{N}^{\circ}$ 7678-2010, recaído en autos SERNAC con Buses Expreso Norte" por el que se rechazó un recurso de queja.

La Corte Suprema, en el segundo de los fallos precedentes, rechazó un recurso de queja interpuesto contra la CA de Santiago, de 7 de octubre de 2010, Ing. No 2093-2010 (la sentencia de la CA, confirmaba la sentencia del $1^{\text {er }} \mathrm{JPL}$ de Estación Central, de 27 de enero de 2010, rol No 2296-2009). La Corte Suprema, en el considerando cuarto de su sentencia, resuelve: “...las reglas de la sana crítica y de la lógica indican que no se puede perseguir las consecuencias o sanciones que a la autoridad le corresponde respecto de las infracciones que afecten, en este caso, los bienes jurídicos de los consumidores, por lo que el plazo de prescripción ha de contarse necesariamente desde que se ha tomado conocimiento de la infracción (lo destacado en cursiva es mío)", y agrega, en el considerando quinto: “...el 16 de septiembre de 2008 se fiscalizó a la Empresa denunciada, y ya a esa fecha podría haber transcurrido el plazo de un año desde que incumplió las obligaciones que le imponía y le impone el artículo 59 del Decreto Supremo $N^{\circ}$ 212/92, infracción que, en la medida que no se haya corregido -como no se ha probado por la apelante haya ocurrido así-, el plazo de prescripción no puede dar inicio a un término por la sola acción del ente fiscalizador, cuánto más si las obligaciones de dicho precepto se entienden instrucciones que han de 
resuelto en algún fallo que, en los casos que los desperfectos posteriores a la compra sean permanentes, la prescripción no comienza a correr mientras subsistan dichos defectos. La solución precedente es criticable, por cuanto la prescripción opera desde que se puede ejercer la acción, lo contrario vendría a significar que la acción no prescribe nunca, por cuanto el defecto puede no cesar jamás ${ }^{61}$.

cumplirse día a día en beneficio de los usuarios de un sistema determinado de trasporte público y masivo de pasajeros. En efecto, el citado artículo 59, que contiene instrucciones permanentes y generales dadas por el Ministerio de Transporte, dice textualmente 'Las empresas que efectúen servicios interurbanos deberán anunciar a los usuarios las tarifas y los horarios de partida y llegada de los diversos servicios que ofrecen al público. Dicho anuncio se hará mediante carteles o pizarras colocadas en un lugar visible de las oficinas de venta de pasajes y se expresarán en dígitos de las siguientes dimensiones mínimas: $2 \mathrm{~cm}$ de alto; $1,5 \mathrm{~cm}$ de ancho y $4 \mathrm{~mm}$ de trazo. Los vehículos con que se presten estos servicios deberán mantener en el interior, en un lugar visible para los pasajeros, un cartel con los horarios de partida y llegada del servicio y otro con las tarifas correspondientes al servicio que efectúan y a los diversos tramos de dicho servicio. Además, en los servicios que consulten paradas entre las 23:30 y las 6:00 horas, deberá anunciarse al usuario el horario de pasada por las distintas ciudades atendidas y el lugar de parada en las mismas o en el cruce del acceso correspondiente, mediante un cartel o pizarra ubicado en cada oficina de venta de pasajes. Si los itinerarios no consultan paradas entre las horas señaladas, bastará 144 con indicar en dicho cartel los lugares de parada en las distintas ciudades comprendidas entre el origen y el destino del recorrido"'; y finalmente, de forma aún más categórica resuelve, en el considerando séptimo: “...por último, y sólo a manera de ejemplo, y con la finalidad de que no quede duda acerca de la conclusión de esta Corte, puede hacerse aquí perfectamente un símil respecto a lo que sucede en el recurso de protección, en que el afectado tiene también un brevísimo plazo para reclamar de los actos ilegales o arbitrarios que lo motivan, el que obviamente se cuenta desde que se haya tenido noticias o conocimiento cierto de los mismos. Es obvio que el SERNAC no puede estar informado día a día de las infracciones a la Ley de los Consumidores, imposibilidad material y jurídica que consiguientemente no puede dejar sin sanción a quien infrinja los derechos fundamentales de las personas, lo que precisamente se encarga de fortalecer lo que dispone precisamente el $\mathrm{N}^{\circ} 26$ del artículo 19 de la Constitución Política de la República” (lo destacado en cursiva es mío).

En igual sentido se inclina una serie de fallos de las cortes de apelaciones. Entre ellos cabe destacar las sentencias de la CA de Santiago, de fecha 7 de mayo de 2008, Ing. N $^{\circ}$ 587-2008, en los autos SERNAC con Inversiones Irribarra Propiedades (dicho fallo revoca una sentencia del $1^{\text {er }}$ JPL de Ñuñoa, de 27 de junio de 2007 y de la CA de San Miguel, de 17 mayo de 2010, Ing. $N^{\circ}$ 187-2000, en autos caratulados SERNAC con Braun Medical S.A., que confirma la sentencia del JPL de San Bernardo, de 18 de enero de 2010, rol No 3422-4-2008.

${ }^{61}$ En la sentencia pronunciada por el Cuarto JPL de Santiago, de fecha 14 de julio de 2006, en el considerando $5^{\circ}$, se resuelve: "si bien la compra del automóvil Chevrolet Corsa, se efectuó en el mes de agosto del año 2005, los desperfectos se presentaron con posterioridad y en diferentes fechas, lo que quiere decir que las imperfecciones que presentó la cosa comprada, se fueron manifestando a través del tiempo, constituyéndose en vicios de defectos sucesivos, que habilitan a la denunciante para perseguir la responsabilidad del proveedor por el automóvil comprado". 
b. Determinación desde cuándo opera la prescripción en la responsabilidad civil

En cuanto a la prescripción de la acción civil se ha estimado que ella se cuenta de acuerdo con las reglas generales. De este modo, para Juan I. Contardo la obligación contractual prescribirá desde que la obligación se hace exigible, conforme al artículo $2514.2^{\circ}$ del $C C C h$, lo que coincide con el incumplimiento de la obligación ${ }^{62}$. Por otra parte, muchos supuestos infraccionales constituirán, a su vez, incumplimientos contractuales. Ello se debe a que las obligaciones que establece la LPDC para el productor se integran al contrato. Si bien estas obligaciones tienen su origen en la ley, se integran al contrato como la regulación de las obligaciones del vendedor del Código Civil se integran a la compraventa. Por ello no se puede señalar que porque se establezca una obligación en la ley, ella es extracontractual. También es posible que se produzcan infracciones a la ley -es decir, que estemos frente a una responsabilidad infraccional- que, de igual forma, constituya un ilícito civil. En este caso, a la obligación extracontractual se le aplica la misma lógica que a la prescripción de la acción infraccional y la prescripción de la acción civil comenzará a correr desde que el consumidor puede ejercerla.

Para finalizar, a pesar de lo generalizada, en la doctrina del consumo, de la aplicación restrictiva del artículo 26 de la LPDC, no es posible dejar de lado que lo reducido de los plazos tiene una razón de ser. Lo reducido de los plazos de prescripción y caducidad se explican por la instantaneidad de la información respecto de la calidad del producto propia del Derecho del Consumo, y la necesidad de no encarecer la contratación masiva, mediante una judicialización excesiva, lo que en definitiva sólo reportaría un perjuicio para el consumidor. Sin perjuicio de lo cual, lo escueto de la actual regulación también puede llevar a soluciones un tanto absurdas,

En igual sentido, el $2^{\circ} \mathrm{JPL}$ de Las Condes, en los autos SERNAC con Falabella SACI, rol $\mathrm{N}^{\circ}$ 29.517, mediante sentencia de 4 de septiembre de 2008, resuelve que respecto de unos chocolates en mal estado, adquiridos en una tienda del Mall Alto Las Condes, la prescripción de la acción infraccional no se cuenta desde la compra, sino desde que el organismo de salud realiza el análisis respectivo por el cual se comprueba que los alimentos estaban contaminados con Salmonella Enteritidis. En este sentido, el referido fallo resuelve, en su considerado quinto: “...en consecuencia dado lo señalado en la motivación anterior, cabe concluir que el plazo de 6 meses a que se refiere el artículo 26 de la Ley $\mathrm{N}^{\circ} 19.496$ (...) debe computarse en este caso, desde que se emitió el informe de la SEREMI de Salud Metropolitana (...), habiéndose interrumpido la prescripción (...) al interponer la denuncia por parte de Sernac (...), por lo que se rechaza la excepción de prescripción...”.

Esta doctrina es consistente con la doctrina del ilícito continuado en materia de prescripción de la acción de responsabilidad extracontractual, sentencia de la CS, de 6 de noviembre de 1981, RDJ, tomo LXXVIII, No 5, Santiago, 1981, p. 326.

${ }^{62}$ Contardo (n. 15), pp. 98-102. 
como las que se han producido en materia de interrupción de la prescripción. Éste no es un tema menor por cuanto la regulación europea en estas materias tiende a generar altos costos de transacción, que, en definitiva, no absorben los productores, sino el propio consumidor.

\section{Modificación del plazo de prescripción extintiva}

El Derecho Común hace la siguiente distinción en torno a si las partes pueden modificar los plazos de prescripción, establecidos por el legislador, sea alargándolos o reduciéndolos:

\section{a. Plazo convencional ampliatorio del lapso de prescripción}

La doctrina de forma casi unánime estima que no pueden aceptarse las estipulaciones de las partes que amplíen los plazos legales de prescripción, porque ello implica una renuncia anticipada, lo cual está prohibido (artículo $2494.1^{\circ}$ del $\left.C C C h\right)^{63}$. Además, la ampliación consensual del plazo legal de prescripción extintivo afectaría de manera grave a esta figura, desde que los plazos de prescripción muy extensos se transformarían en la regla general a través de cláusulas de estilo. Esta posición no es aplicable al Derecho del Consumo por cuanto un plazo extenso de prescripción, 146 dado el plazo excesivamente corto que establece la ley, es algo que podría generar una sana competencia entre productores.

Tampoco se debe considerar per se a una cláusula que regula el plazo de prescripción de la acción del productor como algo negativo, desde que el juez tiene las herramientas para valorar en concreto si dicha cláusula es abusiva. En igual sentido se puede consultar alguna sentencia en materia de consumo ${ }^{64}$.

${ }^{63}$ Ramón Domínguez critica la tesis que admite la reducción del plazo de prescripción, pero no su ampliación como una forma de proteger al deudor. Esta tesis es criticable para el referido autor, desde que, en el Derecho de los Contratos moderno, la parte débil no tiene por qué ser el deudor, es más suele ser el acreedor, como sucede, por ejemplo, respecto de los seguros. El referido autor agrega que si la regulación de la prescripción extintiva es de orden público, naturalmente no se puede disponer del plazo de prescripción. DomínGuEZ (n. 2), pp. 41-46.

${ }^{64}$ La Corte de Apelaciones de Santiago, en la causa SERNAC con Sociedad Comercial Automotriz S.A.”, por sentencia de 9 de julio de 2010, Ing. Corte No 1.093-2010, revocó el fallo del JPL de Quilicura, de fecha 20 de noviembre de 2009, rol No 12.167-3-09, resolvió, en su considerando cuarto: "en cuanto a la excepción de prescripción de la acción alegada por la demandada, el Tribunal estima que las acciones incoadas en autos no se encuentran prescritas, toda vez que las partes pactaron contractualmente una garantía superior a la legal establecida en los artículos antes citados, debiendo comprenderse que si las partes se han obligado voluntariamente a un plazo mayor para ejercer la garantía en caso de desperfecto, debe entenderse que asimismo subsiste la acción de la actora para hacer 
Sin perjuicio de lo anterior, respecto del plazo de garantía legal, el artículo 21 de la LPDC dispone que se puede convenir un plazo más extenso que el de garantía legal de tres meses. En este sentido, la referida norma establece la posibilidad de convenir plazos más extensos de garantía convencional, respecto de los cuales el vendedor suele cobrar un precio. De este modo, el artículo $21.1^{\circ}$ de la LPDC establece:

"el ejercicio de los derechos que contemplan los artículos 19 y 20 deberá hacerse efectivo ante el vendedor dentro de los tres meses siguientes a la fecha en que se haya recibido el producto, siempre que éste no se hubiere deteriorado por hecho imputable al consumidor. Si el producto se hubiere vendido con determinada garantía, prevalecerá el plazo por el cual ésta se extendió, si fuere mayor”.

\section{b. Plazo convencional reductor del lapso de prescripción}

La estipulación de las partes, que tiene por objetivo reducir o limitar el plazo de prescripción, se encuentra en una situación distinta a la precedente. En efecto, en general se estima que es posible reducir el plazo de prescripción, ya que el propio legislador lo admite, como sucede, por ejemplo, en el pacto comisorio, en el contrato de compraventa por incumplimiento de la obligación de pagar el precio. En dicho pacto las partes pueden fijar un plazo de prescripción siempre que sea inferior a cuatro años (artículo 1880 del $C C C h$ ), y otro tanto acontece en los pactos de retroventa (artículo 1885 del $C C C h$ ) y retracto (artículos 1886 del $C C C h)^{65}$. Pero, en ciertos casos, la reducción del plazo puede calificarse como una renuncia al derecho de crédito, por lo que no es admisible.

En algunos cuerpos normativos se admite esta posibilidad, pero sólo respecto de plazos muy extensos y sólo a favor del consumidor ${ }^{66}$. Así, los PECL (artículo 14:601) y la DCFR (artículo III.7:601) permiten los acuer-

exigible la restitución conforme las exigencias técnicas que la propia marca señala para el modelo en cuestión".

${ }^{65}$ Ésta es la posición que se puede considerar como clásica, por cuanto es la seguida por la casi unanimidad de la dogmática civil inmediatamente posterior a la promulgación del Code. En consideración a ella, los acuerdos que extienden en forma excesiva el plazo de prescripción extintiva, darían lugar a una verdadera renuncia anticipada de ella. En cambio, los pactos que la reducen, serían perfectamente válidos, aplicando principios como el favor debitoris. Este razonamiento coindice con la idea de que el objetivo último del Derecho del Consumo es proteger al contratante débil, que en este supuesto sería el consumidor. Pero, estos planteamientos son anacrónicamente erróneos e incompatibles con una economía de mercado.

${ }^{66}$ Así, por ejemplo, en el artículo $134.5^{\circ}$ del Pavia, se permite que las partes puedan convencionalmente reducir el plazo de prescripción de diez años, que se establece en el apartado $4^{\circ}$ de la misma norma; pero sólo a favor del consumidor. 
dos que extienden el plazo de prescripción no más allá de treinta años ${ }^{67}$. A su vez, de acordarse la disminución del plazo de prescripción, éste no puede reducirse a menos de un año. El sustento de esta regulación no puede ser más encomiable, por cuanto evita que los derechos de las partes se transformen en ilusorios. El acreedor no puede adquirir un derecho que en realidad no es tal, si es que se establece un plazo de prescripción excesivamente corto -como podría ser un plazo menor a un año-. Ello equivaldría a permitir el fraude a la ley, presentando contratos como onerosos cuando en realidad son gratuitos. A su vez, la situación inversa por la que se acuerda un plazo excesivamente extenso de prescripción extintiva, significaría en la práctica, como sostiene la doctrina tradicional civil, una renuncia anticipada a la prescripción ${ }^{68}$.

En torno a nuestro Derecho del Consumo, no puede acordarse la reducción del plazo de prescripción, por cuanto ello haría, en definitiva, ilusorios los derechos del consumidor-acreedor; pero lo anterior no implica que no pueda convenirse la reducción o ampliación del plazo de prescripción a favor del consumidor, dependiendo si es deudor o acreedor ${ }^{69}$. Un análisis de estas cláusulas debe hacerse por el juez al tenor de las letras e) y g) del artículo 16 de la LPDC. Por ejemplo, puede ser que un plazo de prescripción muy corto vaya acompañado de una rebaja sustantiva en 148 torno al precio. En dicho caso, el juez debe velar porque el plazo acordado de prescripción no haga ilusorio los derechos del consumidor. En este supuesto, el plazo convenido podría transgredir el artículo 4 de la LPCD, que establece: "los derechos establecidos por la presente ley son irrenunciables anticipadamente por los consumidores”. Esto, sin perjuicio

${ }^{67}$ En realidad esta solución es deudora de los Principios UNIDROIT (artículo 10.3º), que estableció como regla general la modificación de los plazos, pero restringiendo el plazo máximo y mínimo de prescripción.

${ }^{68}$ La mayoría de los ordenamientos jurídicos no admite estos pactos, al otorgarle a las normas que regulan la prescripción un carácter imperativo (artículos: 30 del CC portugués, 129 del $C C$ suizo y $2936 \mathrm{del}$ Codice Civil). Pero la tendencia es a admitir ciertas modificaciones al plazo de prescripción establecido en la ley. Así, en algunos países se aceptan plazos breves y se prohíben los que extienden la prescripción ( $\$ 1502 \operatorname{del} A B G B$ ). En Alemania, el $\S 202$ del $B G B$, aunque en principio prohíbe el convenir acuerdos relativos a la prescripción, sólo se prohíbe acortar anticipadamente los plazos, en caso de dolo del deudor, y alargarlos más allá de treinta años. El Code, sigue la técnica adoptada por los PECL y la $D C F R$, impidiendo acortar el plazo de prescripción a menos de un año e impidiendo alargarlo a más de diez años.

${ }^{69}$ En los contratos de adhesión y de consumo no se puede señalar que per se no se pueda acordar un plazo de prescripción, que favorezca al productor, mediante el simple expediente de señalar que el Derecho del Consumo se centra en la protección del contratante débil, que en la especie sería el consumidor. El análisis de estas cláusulas estará sujeta a un control de contenido, que se regirá por la regulación de las cláusulas abusivas. 
de que el consumidor debe tener conocimiento de la infracción para comenzar a contar el plazo de prescripción y debe tener un plazo razonable dentro del cual pueda ejercer su derecho. Lamentablemente, este tipo de análisis tiene una dificultad adicional, en nuestro Derecho, por cuanto un plazo de prescripción tan corto, como seis meses, hace muy difícil que el juez pueda calificar como razonable un plazo inferior de prescripción.

\section{Interrupción y suspensión de la prescripción extintiva}

La LPDC, hasta antes de la ley No 20.555, de 5 de diciembre de 2011, no se había referido a la interrupción ni a la suspensión de la prescripción. Dicha ley reconocería tímidamente la interrupción, en materia del Derecho del Consumo, en los siguientes términos:

"el plazo contemplado en el inciso precedente se suspenderá cuando, dentro de éste, el consumidor interponga un reclamo ante el servicio de atención al cliente, el mediador o el Servicio Nacional del Consumidor, según sea el caso. Dicho plazo seguirá corriendo una vez concluida la tramitación del reclamo respectivo" ${ }^{70}$.

La ley $\mathrm{N}^{0} 20.555$ reguló una forma de interrupción de forma muy escueta, estableciendo una regla especial, y omitiendo referirse a la interrupción de forma general, y no señaló nada respecto de la suspensión. Por otra parte, es criticable que un reclamo extrajudicial, ante un ente público, se haya calificado como un supuesto de suspensión y no de interrupción.

${ }^{70} \mathrm{El}$ proyecto de reforma, que se plasmaría en la ley $\mathrm{N}^{\mathrm{0}} 19.955$ de 2004 , se refería sucintamente a la suspensión de la prescripción. En su artículo $51.2^{\circ}$ (Primer Informe de la Comisión de Economía, Cámara de Diputados, de 6 de noviembre de 1992, cuenta en sesión 30, legislatura 325, Boletín $\mathrm{N}^{\circ}$ 446-03 1) se sostenía: “el plazo para perseguir la responsabilidad del infractor se suspenderá durante el tiempo que medie entre la fecha del acta de avenimiento y el vencimiento de los plazos que se hayan acordado otorgar al infractor para cumplir las obligaciones que contraiga"; dicho proyecto de norma, conforme al Segundo Informe de la Comisión de Economía (Cámara de Diputados, 11 de mayo de 1993, cuenta en sesión 12, legislatura 326, Boletín $\mathrm{N}^{\circ} 446-03-2$ ), pasaría a ser el artículo $52.2^{\circ}$, disponiéndose: "el plazo para perseguir la responsabilidad del infractor se suspenderá durante el tiempo que medie entre la fecha del acta de avenimiento y el vencimiento de los plazos que se hayan acordado otorgar al infractor para cumplir las obligaciones que contraiga".

Esta regulación en definitiva no prosperó, pero el inciso $2^{\circ}$ del artículo 26 se incorporaría en definitiva mediante la ley No 20.555, de 5 de diciembre de 2011 (Primer Informe de Comisión de Economía Senado. Fecha 2 de mayo de 2011. Cuenta en sesión 13. legislatura 359). Historia de la Ley $\mathrm{N}^{\circ} 19.955$, pp. 65, 186 y 398, y No 20.555, pp. 188, 189, 222, 286, 292, 296, etc., en www.leychile.cl/Consulta/portada_hl. Consultada el 6 de julio de 2012 . 
Por ello se ha optado por denominar a la figura establecida en la norma precedente como interrupción, a pesar de su tenor literal. La suspensión supone una calificación objetiva de imposibilidad o problema en el ejercicio de un derecho; en cambio la interrupción se basa precisamente en el fin de la inacción del acreedor. El que el acreedor-consumidor interponga un reclamo, como es natural, supone el término de su inacción, es decir, la interrupción de la prescripción.

Sin perjuicio de lo anterior, lo que determinará la aplicación de la suspensión y la interrupción es la distinción entre la responsabilidad infraccional, que se regiría por las reglas de la LPDC, y la responsabilidad civil que se regiría por el Código Civil $^{71}$.

Antes de la ley $\mathrm{N}^{0} 20.555$ se discutía si la interrupción se aplicaba conforme a las reglas generales del Código Civil. Y se estimaba que si se aplicaban dichas reglas se requería de notificación de la demanda, dejando de lado que la prescripción del artículo $26.1^{\circ}$, respecto de la responsabilidad infraccional, es una prescripción de corto tiempo, que malamente se puede regir por las reglas de la prescripción de largo tiempo. La ley No 20.555, zanjó este problema estableciendo que el "simple reclamo" suspende la prescripción en los términos ya mencionados. Los tribunales habían abordado de manera adecuada este problema, desechando la exigencia de notificación para un caso de una prescripción de corto tiempo. Así, el fallo de la Corte Suprema, de dieciséis de noviembre de dos mil nueve, rol No 4.921-09, al resolver un recurso de queja contra una sentencia de la Corte de Apelaciones de Concepción, se refiere a este problema. La sentencia de la Corte de Apelaciones resolvió que la prescripción extintiva se interrumpe conforme a las reglas del Código Civil. De este modo, la sentencia de segunda instancia se inclinó a favor de la posición de la demandada, que había alegado que la interrupción se producía sólo desde la notificación de la demanda, conforme a lo estipulado en los artículos $2518.3^{\circ}$ y 2503 del $C C C h^{72}$. La Corte Supre-

${ }^{71}$ En este sentido cabe recordar que el artículo $2523.1^{\circ}$ del $C C C h$ establece: "las prescripciones mencionadas en los dos artículos precedentes corren en contra de toda clase de personas, y no admiten suspensión alguna”.

Sin embargo, aunque la distinción precedente se acogiera de forma generalizada, tendríamos que analizar si la responsabilidad infraccional se rige supletoriamente por las reglas de la prescripción del Código Civil. Plantado este problema en otras palabras, tenemos que preguntarnos si a dicha responsabilidad se le aplica las reglas de la interrupción y suspensión de la prescripción del Código Civil. Al respecto se debe señalar que, a pesar que las prescripciones de corto tiempo del Código Civil no se suspenden, dicha figura se podría aplicar a la acción infraccional. Ello se debe a que la suspensión no opera sólo respecto de las prescripciones de corto tiempo establecidas en los artículos 2521 y 2522 del CCCh. En todo caso, la ley No 20.555 zanjó esta discusión en los términos ya analizados.

${ }^{72} \mathrm{La}$ defensa de la demandada es discutible, aún desde el prisma civil, por cuanto no está claro si la demanda, que se presenta antes que opere el plazo de prescripción, 
ma resolvió que la prescripción se interrumpe conforme a las reglas de la ley $\mathrm{N}^{\mathrm{o}} 18.287$, o sea, desde la presentación de la demanda y no desde su notificación ${ }^{73}$. A dichos argumentos de la Corte Suprema se podría haber

pero que se notifica con posterioridad interrumpe o no civilmente la prescripción. Arturo Alessandri R. señalaba que la interrupción sólo se producía una vez que estuviese notificada la demanda, por cuanto la interrupción sólo puede interrumpir una prescripción en curso. Sin embargo, en la actualidad Daniel Peñailillo sostiene la posición contraria, pues al exigirse la notificación dentro del plazo de prescripción, se estaría alterando el plazo de prescripción; además se estaría discriminando o haciendo diferencias arbitrarias según la facilidad o dificultad de notificación al demandado.

Alessandri Rodríguez, Arturo, Manuel Somarriva Undurraga y Antonio Vodanovic Haklicka, Tratado de los Derechos Reales, $6^{\text {a }}$ ed., Santiago, Editorial Jurídica de Chile, 2005, tomo iI, p. 36 y Daniel Peñailillo Arévalo, Los bienes, la propiedad y otros derechos reales, $4^{\mathrm{a}}$ ed., Santiago, Editorial Jurídica de Chile, 2006, pp. 288-289.

${ }^{73} \mathrm{El}$ referido fallo resuelve, en su considerando octavo, en la parte pertinente: “...es útil tener en cuenta el artículo $50 \mathrm{~B}$ de la Ley $\mathrm{N}^{\mathrm{O}} 19.496$, -desconocido por los jueces recurridos-, que señala: Los procedimientos previstos en esta ley podrán iniciarse por demanda, denuncia o querella, según corresponda. En lo no previsto en el presente párrafo, se estará a lo dispuesto en la Ley 18.287 y en subsidio, a las normas del Código de Procedimiento Civil. (...) [d]ado que la Ley $\mathrm{N}^{\circ} 19.496$ no contiene pauta alguna que regule la interrupción de la prescripción de la acción contravencional ni de la civil, resulta imperativo recurrir a la Ley $\mathrm{N}^{\circ} 18.287$, sobre procedimiento ante los Juzgados de Policía Local, que, por cierto, se complementa con la normativa de la Ley $\mathrm{N}^{\circ} 15.231$, sobre organización y atribuciones de dichos tribunales, en particular, en aquellos aspectos que no fueron rectificados por la Ley $\mathrm{N}^{\circ} 18.287$ (...) Por lo demás, es preciso destacar que los tribunales competentes para conocer de esta clase de acciones individuales que emanan de la Ley sobre Protección de los Derechos de los Consumidores, son, por regla general, precisamente los jueces de policía local, tal como lo estatuye el artículo $50 \mathrm{~A}$ de dicha ley y por tanto, amén de la remisión expresa que esta preceptiva especial hace de las disposiciones de procedimiento contenidas en la Ley $\mathrm{N}^{0} 18.287$, forzoso resulta concluir que igualmente rigen las reglas que gobiernan la organización y atribuciones de este tipo de juzgados, entre las que se encuentra el artículo cuya vulneración invoca el impugnante". El fallo agrega, en su considerando noveno, que, conforme a lo anterior, no cabe recurrir a las reglas de la interrupción de la prescripción del artículo 2514 y siguientes del $C C C h$ : "puesto que (...) existe un precepto especial que trata dicha materia en los procedimientos seguidos ante los Juzgados de Policía Local, como es el artículo 54 de la Ley $\mathrm{N}^{\circ} 15.231$ ”, y, finalmente, resuelve: "sentado lo anterior y en base a los hechos establecidos en el raciocinio sexto, resulta evidente que tanto la acción contravencional como la civil ejercidas por el actor, no se encontraban prescritas, toda vez que desde la fecha de la infracción, asumida por ambas partes y fijada por el propio tribunal el día uno de septiembre de dos mil siete y hasta el ingreso de la demanda ante el juzgado competente, el veintiocho de enero de dos mil ocho, ciertamente no había expirado el tiempo de seis meses que el artículo 26 de la Ley $\mathrm{N}^{0} 19.496$ fija para la prescripción de la acción contravencional, lapso que, por cierto, rige también para las acciones civiles que emanan de dicha ley y que son las tendientes a anular las cláusulas abusivas incorporadas en los contratos de adhesión, obtener la prestación de la obligación incumplida, hacer cesar el acto que afecte el ejercicio de los derechos de los consumidores y a conseguir la debida indemnización de perjuicios o la reparación que corresponda, tal como se colige del artículo 50, inciso segundo, de dicho cuerpo legal”. 
agregado que el plazo de prescripción de seis meses, establecido por el artículo 26 de la LPDC, es extremadamente corto, por lo que exigir la notificación de la demanda conduce a que los derechos del consumidoracreedor sean ilusorios y ello va contra la lógica del Código Civil, que no exige la notificación de la demanda respecto de las prescripciones de corto tiempo (véase artículo $2523.2^{\circ}, \mathrm{N}^{\mathrm{O}} 2$ del $\left.C C C h\right)^{74}$. Por otra parte,

Véase www.poderjudicial.cl/juris_pjud/muestra_doc.php?docid=61045\&row_id=\&todas_ palabras=\&algunas_palabras=\&literal=\&palabra_1=\&proximidad_1=\&proximidad_2=\& proximidad_3=\&proximidad_4=1\&proximidad_5=19496\&proximidad_6=26\&palabra_3 $=\&$ flag_ninguna $=0 \&$ texto $=2$. Consultada el 6 de julio de 2012.

En igual sentido, se pronuncia la Corte Suprema al rechazar un recurso de queja interpuesto contra una sentencia de la Corte de Apelaciones de Santiago, de fecha 7 de octubre de 2010, Ing. No 2093-2010. La sentencia de la Corte de Apelaciones, confirmaba la sentencia del 1er JPL de Estación Central, de 27 de enero de 2010, rol No 2296-2009. De este modo, la Corte Suprema estimó: "la interrupción de la prescripción no se rige por las reglas del Código Civil. El artículo 50 B de la Ley No 19.496, que dispone: 'Los procedimientos previstos en esta ley podrán iniciarse por demanda, denuncia o querella, según corresponda. En lo no previsto en el presente párrafo, se estará a lo dispuesto en la ley 18.287 y, en subsidio, a las normas del Código de Procedimiento Civil'”. Al igual que el fallo precedente la Sexta Sala de la Corte Suprema resuelve, en su considerando tercero: "ahora bien, dado que la Ley $\mathrm{N}^{0} 19.496$ no contiene pauta alguna que regule la interrupción de la prescripción de la acción contravencional ni de la civil, resulta imperativo recurrir a la Ley $\mathrm{N}^{\mathrm{O}}$ 18.287, sobre procedimiento ante los Juzgados de Policía Local, que, por cierto, se complementa con la normativa de la Ley $\mathrm{N}^{\mathrm{O}} 15.231$, sobre organización y atribuciones de dichos tribunales, en particular, en aquellos aspectos que no fueron rectificados por la Ley $\mathrm{N}^{\mathrm{o}} 18.287$ y que tampoco aparecen regulados en este último compendio, como justamente sucede con la interrupción de la prescripción.

Por lo demás, es preciso destacar que los tribunales competentes para conocer de esta clase de acciones individuales que emanan de la Ley sobre Protección de los Derechos de los Consumidores, son, por regla general, precisamente los jueces de policía local, tal como lo estatuye el artículo $50 \mathrm{~A}$ de dicha ley y por tanto, amén de la remisión expresa que esta preceptiva especial hace de las disposiciones de procedimiento contenidas en la Ley $\mathrm{N}^{\mathrm{o}} 18.287$, forzoso resulta concluir que igualmente rigen las reglas que gobiernan la organización y atribuciones de este tipo de juzgados, entre las que se encuentra el artículo 54 de la Ley $\mathrm{N}^{\mathrm{O}} 15.231$ ”. Véase www.poderjudicial.cl/juris_pjud/muestra_doc. php?docid $=68516 \&$ row_id $=\&$ todas_palabras $=\&$ algunas_palabras $=\&$ literal $=\&$ palabra _1=\&proximidad_1=\&proximidad_2=\&proximidad_3=\&proximidad_4=1\&proxim idad_5=19.496\&proximidad_6=26\&palabra_3=\&flag_ninguna=0\&texto=2 y http:// www.poderjudicial.cl/juris_pjud/muestra_doc.php?docid $=61045 \&$ row_id=\&todas_ palabras $=\&$ algunas_palabras $=\&$ literal $=\&$ palabra_1=\&proximidad_1=\&proximidad_2= \&proximidad_3=\&proximidad_4=1\&proximidad_5=19.496\&proximidad_6=26\&palab ra_3=\&flag_ninguna $=0 \&$ texto $=2$

${ }^{74}$ Incluso algunos autores y sentencias de los tribunales, interpretando el artículo $2523.2^{\circ}, \mathrm{N}^{\circ} 2$ del $C C C h$-que sólo exige de requerimiento para que opere la interrupción de la prescripción-, han sostenido que la mera interpelación extrajudicial interrumpa la prescripción de corto tiempo. René Abeliuk Manasevich, Las obligaciones, Santiago, Editorial Jurídica de Chile, 1993, tomo I, pp. 1029-1030. 
no olvidemos que conforme a una doctrina, a la cual nos adscribimos, el artículo 26 de la LPDC sólo se aplica a la prescripción y caducidad de la responsabilidad infraccional, y no a la acción civil. Para esta doctrina la responsabilidad civil -aun la que proviene de la culpa infraccional por violación de la LPDC- se rige por las reglas del Código Civil. Por consiguiente, si se estima que la acción estatutaria se rige por las reglas de la responsabilidad contractual, la acción prescribirá dentro de los cinco años desde que la obligación se hizo exigible. Y ella se rige por las reglas del Código Civil en cuanto a la prescripción extintiva, por lo que se aplicarían las reglas que rigen la interrupción y la suspensión de las prescripciones de largo tiempo. Y consecuentemente con ello se aplicarán las reglas de la interrupción de la prescripción. A su vez, para esta doctrina ambas acciones son independientes ${ }^{75}$; en cambio, para un número considerable de sentencias de los tribunales, de prescribir la pretensión infraccional, conforme al artículo 26 de la LPDC, caduca la acción civil.

Estas conclusiones se ven reforzadas si se recurre al Derecho Comparado. De esta forma, los artículos 14:301 del PECL y III-7:301 de la DCFR suspenden la prescripción, por lo cual el plazo no comienza a correr, cuando el acreedor ignora o no pueda razonablemente conocer la identidad del deudor o los hechos que hayan dado lugar a su pretensión. De este modo, el acreedor debe haber tenido la posibilidad real de reclamar su derecho para que opere la prescripción extintiva. También se suspende la prescripción, de acuerdo con estos instrumentos, en dos situaciones más. La primera es en la medida que se haya iniciado, por parte del acreedor, un procedimiento judicial o extrajudicial contra el deudor (artículos 14:302 de los PECL y III-7:302 de la DCFR). En los PECL la suspensión procede respecto de cualquier procedimiento arbitral y cualesquier otro que se inicien para obtener un título ejecutivo, las DCFR agregan la mediación $y$ a cualquier otro equivalente jurisdiccional en que se acuda al arbitrio de un tercero para que éste adopte una decisión relativa al derecho en cuestión. Y, finalmente, se suspende la prescripción cuando el acreedor no pueda ejercer su derecho por un impedimento que se encuentre fuera de su control; pero sólo en la medida que dicho impedimento impida dicho ejercicio, durante los últimos seis meses del plazo de prescripción. Pero, además de la suspensión de la prescripción, los PECL y la $D C F R$

${ }^{75}$ Ésta es la posición planteada por Gonzalo Cortéz Matcovich, Emilio Pfeffer Urquiaga, José Luis Guerrero Becar y Ruperto Pinochet Olave, para los cuales este problema ni siquiera se presenta por cuanto las reglas de la prescripción del Código Civil se aplican en su integridad a la acción civil, que emana de la infracción a la LPDC, es decir, el acreedor tiene un plazo de cinco años, desde que la obligación se hizo exigible que prescribe conforme a las reglas generales, plazo que se interrumpe y suspende conforme a las regla del Código Civil. 
establecen la posposición del término del plazo de prescripción en caso que las partes entren en negociaciones para alcanzar un acuerdo (artículo 1:201 de los PECL); en los casos de incapacidad, cuando no existe representación (artículos 14:305 de los PECL y III-7:205 de la DCFR), y en caso de fallecimiento del acreedor o deudor. En este último supuesto se pospone el momento de la prescripción de las pretensiones a favor o en contra de la herencia. El primer supuesto, señalado precedentemente, como destacan, Andrés Domínguez Luelmo y Henar Álvarez Álvaez, consiste en una aplicación del principio de la buena $\mathrm{fe}^{76}$.

Para finalizar, la LPDC estableció, en el párrafo $2^{\circ}$ del título IV, reglas que regulan el procedimiento para la defensa de los intereses colectivos o difusos. La ley $\mathrm{N}^{\mathrm{O}} 20.543$ de 2011, agregó al artículo 50 de la LPDC, un numeral $6^{\circ}$, que estableció:

"la presentación de la demanda producirá el efecto de interrumpir la prescripción de las acciones indemnizatorias que correspondan a los consumidores afectados. Respecto de las personas que reservaren sus derechos conforme al artículo $54 \mathrm{C}$ el cómputo del nuevo plazo de prescripción se contará desde que la sentencia se encuentre firme y ejecutoriada".

De este modo, después de promulgación de la ley $\mathrm{N}^{0} 20.543$, no se puede exigir notificación de la demanda para interrumpir la prescripción. No nos olvidemos que las demandas por derechos difusos se presentan ante

${ }^{76}$ En dicho caso el plazo de prescripción no vence hasta que haya transcurrido un año desde la última comunicación realizada a lo largo de las negociaciones. Domínguez y Álvarez (n. 6), p. 17.

En los casos de incapacidad cuando no existe representación, conforme a los artículos 14:305 PECL y III-7:205 de la DCFR, el plazo de prescripción de las acciones a favor o en contra del incapaz no se agota hasta que haya transcurrido un año desde que desapareció su incapacidad o desde que se le hubiera designado un representante. Cuando el incapaz tiene representante, se regula igualmente el plazo de prescripción de las acciones que aquél tiene frente a su representante. Dicho plazo no expira hasta que transcurra un año desde que desapareció la incapacidad o desde que se designa nuevo representante.

En algunos países, como Alemania ( $\$ 208$ del $B G B$ ), se contempla expresamente la suspensión de la prescripción de las pretensiones que surjan al amparo de una lesión al derecho a la libertad sexual de los menores. Como es posible que la persona que ha cometido los abusos sea uno de los padres del menor, el supuesto no encuentra buen acomodo dentro de los casos de vencimiento diferido, teniendo en cuenta que el menor necesita bastante tiempo para superar las barreras psicológicas que le haya ocasionado el trauma. Por ello, para Andrés Domínguez y Henar Álvarez, es preferible inclinarse por el artículo III-7:303 de la $D C F R$, que permite suspender la prescripción respecto de los hechos impeditivos sicológicos dentro de los impedimentos que se encuentra fuera del control de acreedor. Domínguez y Álvarez (n. 6), pp. 17-18. 
Juzgado de Letras en lo Civil (artículo 50, A. $3^{\circ}$ de la LPDC). En esta ocasión nuestro legislador no confundió la interrupción con la suspensión de la prescripción.

\section{Las reglas de responsabilidad civil supletorias al Derecho del Consumo}

Una pregunta que nos debemos formular es si el Derecho del Consumo no es un Derecho de mínimos, que de agotarse siempre permite recurrir a las reglas de la responsabilidad civil del Derecho Común, sobre todo a favor del consumidor. Este tema es sumamente relevante en torno a la prescripción extintiva establecida en el artículo 26 de la LPDC. Ello se debe a que el plazo establecido en la norma citada es en extremo corto, se trata de un plazo de seis meses. Lo cual nos lleva a analizar si transcurrido dicho plazo subsisten las acciones de Derecho Común. El artículo 26 de la LPDC, al referirse a "la responsabilidad contravencional que se sanciona por la presente ley", nos da la idea de que siempre se aplicará en subsidio el Derecho Común. Por lo cual, la regla de prescripción extintiva común -en contraposición a esta regla de prescripción específica- dependerá de la prescripción de la obligación in natura. Lo anterior es una distinción relevante por cuanto el plazo de prescripción de la resolución en nuestro Derecho en realidad no es de cinco años, como sostiene una parte importante de la doctrina, sino que equivale al plazo de prescripción de la acción que emana de la obligación in natura. De este modo, en la medida que la acción de cumplimiento forzado esté prescrita, la acción de resolución y la indemnización de perjuicios también lo estarán (eso es relevante, en especial, para las acciones de corto tiempo). Ello nos lleva a apreciar la excepcionalidad del artículo 1880 del $C C C h$, que separa artificialmente la prescripción de la acción resolutoria del derecho principal ${ }^{77}$.

${ }^{77}$ Sin perjuicio de lo anterior, en el Derecho Comparado, para una parte de la doctrina, el derecho a solicitar la resolución no puede sobrevivir al derecho a solicitar el cumplimiento forzado. Esto es especialmente importante en las prescripciones denominadas de corto tiempo. En este sentido, José Mélich-Orsini señala: "en la doctrina se indica, además, que la acción de resolución en sí misma, en cuanto derecho potestativo, es imprescriptible y que lo que prescribe es el crédito cuya falta de cumplimiento da lugar a que se pida el cumplimiento o la resolución, por lo que el derecho a pedir la resolución en cuanto tal, subsiste mientras subsista el crédito (se cita a Rafael Álvarez Vigaray). Esto nos dice que el lapso para intentar la acción de resolución dura tanto como dura el período para pedir el cumplimiento, por lo cual, si el crédito de cuyo incumplimiento se trate es de los que tiene un lapso de prescripción menor de diez años, por ejemplo, está sujeto a una prescripción de dos años, para invocar la prescripción de la acción de resolución fundada en el incumplimiento de ese crédito es suficiente con que se haya consumado ese lapso de dos años, y de ninguna manera podrá objetarse que no han transcurrido los 
Por estas razones se debe concluir que la "responsabilidad infraccional" se separara del Derecho Común y el acreedor-consumidor mantiene los derechos que este estatuto le confiere. Lo anterior es, sin perjuicio de que para parte de nuestra doctrina, el acreedor sólo tendrá una acción de responsabilidad extracontractual por los ilícitos contravencionales, que se aprecian en concreto.

Por último, el artículo 26 de la LPDC no establece quién debe probar desde cuándo se produce la infracción, por lo que se debe recurrir a la regla general del artículo $1689 \mathrm{del} C C C h$, es decir, la prueba corresponderá al deudor que alega que se ha extinguido la responsabilidad.

\section{Determinación del estatuto que rige la responsabilidad civil que deriva de la responsabilidad infraccional}

Como se verá no es pertinente analizar qué reglas se aplican supletoriamente a la responsabilidad civil, que se desprende de la responsabilidad infraccional, sino, simplemente, calificarla en concreto, como contractual, que será la regla general o extracontractual. Los criterios de imputabilidad infraccional estarían constituidos por la transgresión al derecho del consumidor establecido en la LPDC, que también es un elemento integrante de la responsabilidad infraccional. Naturalmente la responsabilidad contravencional daría lugar a las sanciones que la LPDC establece ${ }^{78}$. En este sentido se puede recurrir a la distinción entre consumidor jurídico, que será el adquirente de la cosa o servicio, y consumidor material, que es el tercero que adquiere sin vínculo contractual con el productor. El primero se rige por el estatuto de la responsabilidad contractual y el segundo por la responsabilidad extracontractual ${ }^{79}$.

diez años (se cita a Rafael Álvarez Vigaray)" (lo señalado entre paréntesis es mío). José MéLich-Orsini, La resolución del contrato por incumplimiento, Caracas, Serie Estudios, Arauco Ediciones C.A., 2003, p. 322.

${ }^{78}$ Para Francisco Fernández este criterio de imputabilidad objetivo, que se configura por la transgresión a la LPDC, da lugar a responsabilidad que "no comportan negligencia ni mala fe por parte del proveedor, pero como quiera que dan lugar a una ruptura de la conmutatividad del contrato de consumo en perjuicio del consumidor, la ley les asigna a una sanción de índole civil que en cada caso determina y que, en general, consiste en el deber de resarcir al consumidor afectado”. Fernández (n. 1), p. 23.

${ }^{79}$ Erika Isler al respecto nos señala: "según Rony Jara, al consumidor material le corresponden todos los derechos emanados de los eventuales daños producidos por productos defectuosos, configurándose en este caso un supuesto de responsabilidad extracontractual. Al consumidor jurídico en tanto, le corresponden además otras garantías especiales, tales como las derivadas de los contratos por adhesión, configurándose en este caso una hipótesis de responsabilidad contractual". Erika IsLER SOTO, El concepto de producto defectuoso en la ley de protección de los derechos de los consumidores, Santiago, tesis para optar al 
Sin embargo, la responsabilidad civil, que se desprende de la normativa del Derecho del Consumo, nos parece que a lo menos conceptualmente tiene un origen contractual, lo que plantea dos formas de ver este fenómeno. La primera es entender, que las reglas que regulan el Derecho del Consumo integran el haz normativo del contrato (tesis del negocio jurídico u objetiva) y la segunda es comprender que el Derecho del Consumo se integra al contrato a través de la buena fe (tesis convencional o subjetiva).

La configuración del Derecho del Consumo, a través de la responsabilidad extracontractual, aunque perfectamente posible, nos parece que es discutible; pero éste es un tema que excede al análisis del artículo 26 de la LPDC.

\section{Principales conclusiones en torno a la prescripción extintiva y la caducidad tanto de la acción civil, como de la infraccional en la ley de protección del consumidor}

1. Conclusiones específicas

a. La clasificación entre prescripción y caducidad es esencial para determinar la forma en que opera un plazo extintivo en ambas figuras. Esta distinción se presenta tanto en el Derecho Comparado, como en el nuestro y tiene especial relevancia en el Derecho del Consumo.

b. Las principales conclusiones de este trabajo se refieren al ámbito de aplicación del artículo $26.1^{\circ}$ de la LPDC. En esta materia se enfrentan fundamentalmente dos posiciones. La primera de ellas presenta dos modalidades. La principal consiste en que la prescripción de la acción infraccional hace caducar la acción civil, que emana de la responsabilidad civil y la segunda, extiende el ámbito de aplicación del artículo $26.1^{\circ}$ de la LPDC a ambas responsabilidades.

Las posiciones precedentes son fundamentalmente jurisprudenciales y han sido criticadas con fuerza por la doctrina, que ha levantado una segunda posición, que también tiene dos variantes. En virtud de la primera, el ámbito de aplicación del artículo $26.1^{\circ}$ de la LPDC se limitaría a la responsabilidad infraccional, que cumple una función preventiva o sancionatorio en el Derecho del Consumo. Por lo que la responsabilidad civil, que emana del Derecho del Consumo, se regiría por las reglas generales del Código

grado de magíster en Derecho, mención Derecho Privado, Universidad de Chile, 2011, p. 29 y Rony Jara Amigo, “Ámbito de aplicación de la ley chilena de protección al consumidor: inclusiones y exclusiones”, en Cuadernos de Extensión Jurídica, N 3, Santiago, 1999, p. 62. 
Civil. Esta posición nos llevaría a distinguir entre dos formas de prescripción: la responsabilidad contractual, respecto del consumidor jurídico y la responsabilidad extracontractual, respecto del consumidor material. Una segunda variante de esta posición limita aún más el ámbito de aplicación del artículo $26.1^{\circ}$, pues excluye de la norma los supuestos infraccionales que generan efectos civiles, y no preventivos. Así se explica que la acción de nulidad, que proviene de la infracción de las cláusulas negras y grises, y que configura una cláusula abusiva, se regiría por los plazos de saneamiento de la nulidad y no por el artículo $26.1^{\circ}$ de la LPDC.

c. De la regulación de la LPDC se desprenden criterios de imputabilidad objetiva, que estarían dados por la responsabilidad infraccional que, a su vez, sirve de base para una responsabilidad estatutaria del consumo, que puede ser tanto contractual como extracontractual.

d. Los tribunales han resuelto, independiente de las dos posiciones fundamentales en torno al ámbito de aplicación del artículo $26.1^{\circ}$ de la LPDC, en muchos casos acertadamente, problemas complejos, como la determinación desde cuándo se cuenta la prescripción extintiva. A su vez, en forma reciente la ley $\mathrm{N}^{\mathrm{o}} 20.555$, incorporó un nuevo inciso $2^{\circ}$ al artículo $26.1^{\circ}$ de la LPDC, que impide que la prescripción extintiva se interrumpa conforme a las reglas generales del $C C C h$. Sin perjuicio de lo cual, la notificación de la demanda para interrumpir la prescripción no era necesaria por cuanto el artículo $26.1^{\circ}$ de la LPDC establecía una prescripción de corto tiempo. La posición que exigía notificación de la demanda podría haber hecho ilusorios los derechos del consumidor. Afortunadamente, los tribunales no acogieron esta posición, que por lo demás, aún antes de la reforma de la ley $\mathrm{N}^{\mathrm{o}} 20.555$, era insostenible. Lo anterior es independiente que la norma en comento califica como suspensión un supuesto de interrupción.

e. La doctrina que distingue estatutos regulatorios en la LPDC, aunque interesante, es artificial y demasiado compleja; por lo demás el Derecho de Consumo tiene una lógica propia que esta posición no considera. Es verdad que la doctrina de consumo está muy imbuida en "la protección del contratante débil", pero es más que dudoso el que éste sea un principio generalmente reconocido en el Derecho chileno ${ }^{80}$.

${ }^{80}$ Esta aseveración requiere de una justificación mayor, que, lamentablemente, no es posible abordar en un trabajo de estas dimensiones. Sin embargo, el Derecho del Consumo debe fundarse en consideraciones económicas y en especial en lo que se denomina como fallas de mercado, más que en un sistema de orden público, similar al Derecho Laboral. 
2. Conclusión general en torno a la regulación de la prescripción y distinciones doctrinales

El análisis precedente ha puesto de relieve las insuficiencias regulatorias de la LPDC ${ }^{81}$. Sin embargo, nuestra doctrina ha rehuido abordar el tema esencial del Derecho del Consumo, que no es otro que el modelo de regulación que se ha adoptado. Es verdad que respecto al modelo normativo del Derecho del Consumo debe haber tantas posiciones como autores ${ }^{82}$; pero la LPDC tiene un espíritu propio. Tiende a proteger al consumidor, pero de una forma débil por cuanto el legislador no estaba convencido de la aplicación irrestricta de criterios basados sólo en "la protección del contrate débil”, ya que ellos pueden aumentar los costos de la contratación. Dichos costos al ser transferidos al consumidor, llevaría a que, en definitiva, se le protegiera malamente. En este sentido, lo que el artículo $26.1^{\circ}$ de la LPDC hace es aplicar un muy criticable corto plazo de prescripción extintiva, pero que tiene el sentido de exigir una mayor diligencia en el ejercicio de los derechos por parte del consumidor, y del propio SERNAC. A pesar de que la técnica legislativa no es de las mejores, los tribunales, de una u otra forma, han optado por soluciones razonables, las que no se basan en el principio "la protección del contratante débil". La doctrina de consumo también ha hecho un esfuerzo encomiable de reconducción, frente a ciertos vacíos normativos, a las reglas generales del Derecho Civil; pero ése no es el camino adecuado, desde que necesariamente debemos reconocer en el Derecho del Consumo ciertas particularidades, que lo diferencian de las reglas del Derecho Común plasmadas en el Código Civil.

\section{SENTENCIAS CITADAS}

Corte Suprema, 15 de julio de 2009, Ing. No 3774-09.

Juzgado de Policía Local de Renca, 9 de diciembre de 2008, rol No 8029-1-06.

${ }^{81}$ De este modo, autores como Carlos Pizarro o Iñigo De la Maza han realizado duras críticas a la regulación del consumo, a través de la ley No 19.496 , críticas a la cual, conforme a lo señalado, sólo cabe sumarse. Carlos Pizarro Wilson, "El fracaso de un sistema: análisis empírico y dogmático del control de cláusulas abusivas en contratos por adhesión”, en Revista de Derecho, vol. 20, No 2, Valdivia 2007, en línea, pp. 31-47, consultada el 6 de julio de 2012 e Iñigo DE LA MAZA GAZMURI, “¿Llegar y llevar?: una mirada al crédito de las casas comerciales”, en Revista de Derecho vol. 20, N 1, Valdivia, 2007, en línea, pp. 61-84. Consultada el 6 de julio de 2012.

${ }^{82}$ En este sentido a mí me parece que sería conveniente relacionar el Derecho del Consumo con las Condiciones Generales de la Contratación y la regulación de la libre competencia como un estatuto único. Estatuto que, además debe estar íntimamente relacionado con las fallas de mercado (colusión de precios, asimetrías de información, conductas oportunistas, externalidades positivas y negativas, costos de transacción, etcétera). 
Corte de Apelaciones de San Miguel, 17 de mayo de 2010, Ing. No 187-2010.

Muñoz con Mueblería Peña y Morales, 3 $3^{\text {er }}$ JPL Antofagasta, 26 de agosto de 2008, rol No 5.216/2008.

Ehrenfeld con Hipermercado Lider Antofagasta, $3^{\text {er }}$ JPL Antofagasta, 12 de septiembre de 2008, rol No 6.656/2008).

Corte de Apelaciones de Santiago, 19 de septiembre de 2008, rol 5587-2008.

Juzgado de Policía Local de Antofagasta, 26 de agosto de 2008, rol No 5216-2008.

Juzgado de Policía Local de Antofagasta, 15 de julio de 2008, rol No 3704-2008.

Juzgado Policía Local de Antofagasta, 30 de junio de 2009, rol No 3788.2009.

Corte de Apelaciones de Temuco, 4 de diciembre de 2008, rol No 934-2008.

Corte de Apelaciones de Antofagasta, 5 de febrero de 2009, rol N ${ }^{\circ} 143-2008$.

Tercer Juzgado de Policía Local de Antofagasta, 26 de octubre de 2008, rol No 7325-2008.

Segundo Juzgado de Policía Local de Maipú, 17 de julio de 2007, rol No 5265-2006.

Corte de Apelaciones de La Serena, 8 de agosto de 2007, rol No 144-2007.

Corte de Apelaciones de Concepción, de 5 de noviembre de 2009, rol ingreso No 231-09.

Corte de Apelaciones Concepción 24 de diciembre de 2007, rol 174-2005.

160 Corte de Apelaciones de Concepción, 28 de noviembre del 2008, rol No 66.186

Corte de Apelaciones de Santiago, 26 de diciembre del 2002, rol No 5437-2000.

Corte de Apelaciones de San Miguel, 31 de enero de 2009, rol No 1141-2008

Corte de Apelaciones de Santiago, 14 de agosto del 2009, rol No 8424-2009.

Corte de Apelaciones de Santiago, 24 de marzo del 2010, rol No 179-2010.

Corte de Apelaciones de Santiago, 12 de mayo del 2009, rol No 19.497.

Tercer Juzgado de Policía Local de Santiago, 12 de enero de 2007, rol No 9936-06.

Primer Juzgado de Policía Local de Puerto Montt, de 23 de enero de 2007, rol $\mathrm{N}^{\mathrm{o}} 4956-2006$.

Corte Suprema, 1 de septiembre de 2009, Ing. N 5.858-2009.

Segundo Juzgado de Policía Local de Las Condes, 4 de septiembre de 2008, rol $\mathrm{N}^{\mathrm{O}} 29.517$.

Corte de Apelaciones de Santiago, 9 de julio de 2010, Ing. Corte No 1.093-2010.

Corte Suprema, 16 de noviembre de 2009, rol No 4.921-09.

Corte de Apelaciones de Santiago, 7 de octubre de 2010, Ing. No 2093-2010, rol No 2296-2009. 


\section{BiBLIOGRAFÍA}

Abeliuk Manasevich, René, Las obligaciones, Santiago, Editorial Jurídica de Chile, 1993, tomos I y II.

Alessandri Rodríguez, Arturo, Manuel Somarriva Undurraga y Antonio Vodanovic Haklicka, Tratado de los Derechos Reales, $6^{\mathrm{a}}$ ed., Santiago, Editorial Jurídica de Chile, 2005, tomo II.

Alonso Traviesa, María Teresa, El problema de la concurrencia de responsabilidades, Santiago, Lexis Nexis, 2006.

Arce Flórez-VAldés, Joaquín, "Extinción del contrato y de las relaciones que nacen del mismo", en Código Europeo de Contratos, Pavia, Italia, Academia de Iusprivatistas Europeos, 2003, tomo II.

Barrientos Camus, Francisca, "Derecho del Consumo", en Revista Chilena de Derecho Privado, No 17, Santiago, diciembre 2011.

Barrientos Camus, Francisca, Iñigo De la Maza Gazmuri y Carlos Pizarro Wilson, Consumidores, Santiago, AbeledoPerrot y Thomson Reuters, Fundación Fueyo, 2012.

Barros Bourie, Enrique, Tratado de responsabilidad extracontractual, Santiago, Editorial Jurídica de Chile, 2006.

Bercovitz Rodríguez-Cano, Rodrigo, Comentarios a la Ley de Condiciones Generales de la Contratación, Navarra, Aranzadi Editorial, 2000.

CAPRile Biermann, Bruno, "Las acciones del comprador insatisfecho: el cúmulo actual (Ley de Protección al Consumidor, vicios redhibitorios, error sustancial, resolución por incumplimiento) y la tendencia al deber de conformidad en el Derecho comparado", en Fabricio Mantilla Espinosa y Carlos Pizarro Wilson (coordinadores), Estudios de Derecho Privado en homenaje a Christián Larroumet, Santiago, Ediciones de la Fundación Fernando Fueyo Laneri, 2008.

Caprile Biermann, Bruno, "Las acciones del comprador insatisfecho: el cúmulo actual y la tendencia al deber de conformidad", en Hernán CORRAL y María Rodríguez, Estudios de Derecho Civil II (IV Jornadas de Derecho Civil), Olmué, Santiago Lexis Nexis, 2006.

Contardo González, Juan Ignacio, "Prescripción de la acción indemnizatoria en la Ley de Protección al Consumidor: tendencias jurisprudenciales", en Cuadernos de Extensión Jurídica, No 21, Santiago, Universidad de los Andes, 2011.

Contez Matcovich, Gonzalo, El nuevo procedimiento regulado en la Ley $N^{o} 19.496$ sobre Protección de los Derechos de los Consumidores, Santiago, Lexis-Nexis, 2004.

Corral Talciani, Hernán, Responsabilidad por productos defectuosos, Santiago, Abeledo Perrot, LegalPublishing, 2011.

De la Maza Gazmuri, Iñigo, "¿Llegar y llevar?: una mirada al crédito de las casas comerciales", en Revista de Derecho vol. 20, No 1, Valdivia, 2007, en línea. 
Díez-Picazo y Ponce de León, Luis y Aurelio Ménendez Menéndez (directores), Jesús Alfaro Águila-Real, Comentarios a la Ley sobre Condiciones Generales de la Contratación, Madrid, Civitas, 2002.

Domínguez Águila, Ramón, La prescripción extintiva. Doctrina y jurisprudencia, Santiago, Editorial Jurídica de Chile, 2004, Nº 28.

Domínguez Luelmo, Andrés y Álvarez Álvaez, Henar, "La prescripción en los $P E C L$ y en el DCFR", en INDRET, $\mathrm{N}^{\circ} 3,2009$, disponible en www.indret. com/pdf/654_es.pdf.

Elorriaga de Bonis, Fabián, "Del día de inicio del plazo de prescripción de una acción indemnizatoria cuando el perjuicio se ha manifestado con posterioridad al hecho que lo origina", en Cuadernos de Extensión Jurídica, No 21, Santiago, Universidad de los Andes, 2011.

Escalona Riveros, Francisco, La prescripción extintiva civil, Santiago, Conosur, 1997.

Fernández Fredes, Francisco, Manual de Derecho chileno de protección al consumidor, Santiago, Editorial Lexis Nexis, 2003.

GonZÁlez Blanco-Rachewsky, Zinaída, "Japón: nueva ley de responsabilidad civil por los daños causados por productos defectuosos", en Estudios sobre consumo, $\mathrm{N}^{\mathrm{o}}$ 1, España, octubre 1994.

Guerrero BeCAR, José Luis, "La distinción entre contravención infraccional e 162 incumplimiento contractual o contravención civil en materia de protección de derechos del consumidor", en Alejandro Guzmán Brito (coord)., Colección de estudios de Derecho Civil en homenaje a la profesora Inés Pardo de Carvallo, Valparaíso, Ediciones Universitarias de Valparaíso, 2008.

Isler SOTO, Erika, El concepto de producto defectuoso en la ley de protección de los derechos de los consumidores, Santiago, tesis para optar al grado de magíster en Derecho, mención Derecho Privado, Universidad de Chile, 2011.

JaRA Amigo, Rony, "Ámbito de aplicación de la ley chilena de protección al consumidor: inclusiones y exclusiones", en Cuadernos de Extensión Jurídica, No 3, Santiago, 1999.

Lagos Villarroel, Osvaldo, "Para una recepción crítica de la caducidad", en Revista Chilena de Derecho Privado, No 4, Santiago, julio 2005.

LiRa URquieta, Pedro, "Concepto jurídico de caducidad y prescripción extintiva", en Revista de Derecho y Jurisprudencia, edición bicentenario, doctrinas esenciales, derecho civil, obligaciones, tomo II, Santiago, 2009.

Mélich-Orsini, José, La resolución del contrato por incumplimiento, Caracas, Serie Estudios, Arauco Ediciones C.A., 2003.

Peñailillo Arévalo, Daniel, Los bienes, la propiedad y otros derechos reales, $4^{\mathrm{a}}$ ed., Santiago, Editorial Jurídica de Chile, 2006.

Pinochet Olave, Ruperto, “ $\mathrm{iEs}$ necesaria la condena infraccional como requisito de procedencia a la indemnización de perjuicios regulada en la Ley 19.496 sobre protección del consumidor? Un error histórico”, en Fabián ELORRIAGA 
De Bonis (coord.), Estudios de Derecho Civil VII. Jornadas Nacionales de Derecho Civil, Viña del Mar, Santiago, Thomson Reuters-AbeledoPerrot, 2011.

PiZARro Wilson, Carlos, "El fracaso de un sistema: análisis empírico y dogmático del control de cláusulas abusivas en contratos por adhesión”, en Revista de Derecho, vol. 20, No 2, Valdivia 2007, en línea.

Reglero Campos, L. Fernando, "La prescripción de la acción de reclamación de daños", en Fernando Reglero Campos (coord.), Lecciones de responsabilidad civil, Navarra, España, Aranzadi, 2002.

Román García, Antonio, "Prescripción y caducidad", en Código Europeo de Contratos, Pavia, Italia, Academia de Iusprivatistas Europeos, 2003, tomo II.

SAndoval López, Ricardo, Derecho del Consumidor, Santiago, Editorial Jurídica de Chile, 2004. 